\title{
RESEARCH
}

Open Access

\section{Anti-inflammatory activity of Wnt signaling in enteric nervous system: in vitro preliminary evidences in rat primary cultures}

\author{
Rosa Di Liddo ${ }^{1 *+}$, Thomas Bertalot ${ }^{1 \dagger}$, Anne Schuster ${ }^{2}$, Sandra Schrenk², Alessia Tasso ${ }^{1}$, Ilenia Zanusso ${ }^{1}$,
} Maria Teresa Conconi ${ }^{1 \dagger}$ and Karl Herbert Schäfer ${ }^{2+}$

\begin{abstract}
Background: In the last years, Wnt signaling was demonstrated to regulate inflammatory processes. In particular, an increased expression of Wnts and Frizzled receptors was reported in inflammatory bowel disease (IBD) and ulcerative colitis to exert both anti- and pro-inflammatory functions regulating the intestinal activated nuclear factor KB (NF-KB), TNFa release, and IL10 expression.

Methods: To investigate the role of Wnt pathway in the response of the enteric nervous system (ENS) to inflammation, neurons and glial cells from rat myenteric plexus were treated with exogenous Wnt3a and/or LPS with or without supporting neurotrophic factors such as basic fibroblast growth factor (bFGF), epithelial growth factor (EGF), and glial cell-derived neurotrophic factor (GDNF). The immunophenotypical characterization by flow cytometry and the protein and gene expression analysis by QPCR and Western blotting were carried out.
\end{abstract}

Results: Flow cytometry and immunofluorescence staining evidenced that enteric neurons coexpressed Frizzled 9 and toll-like receptor 4 (TLR4) while glial cells were immunoreactive to TLR4 and Wnt3a suggesting that canonical Wnt signaling is active in ENS.

Under in vitro LPS treatment, Western blot analysis demonstrated an active cross talk between canonical Wnt signaling and NF-KB pathway that is essential to negatively control enteric neuronal response to inflammatory stimuli. Upon costimulation with LPS and Wnt3a, a significant anti-inflammatory activity was detected by RT-PCR based on an increased IL10 expression and a downregulation of pro-inflammatory cytokines TNFa, ILIB, and interleukin 6 (IL6). When the availability of neurotrophic factors in ENS cultures was abolished, a changed cell reactivity by Wnt signaling was observed at basal conditions and after LPS treatment.

Conclusions: The results of this study suggested the existence of neuronal surveillance through FZD9 and Wnt3a in enteric myenteric plexus. Moreover, experimental evidences were provided to clarify the correlation among soluble trophic factors, Wnt signaling, and anti-inflammatory protection of ENS.

Keywords: Wnt signaling, Frizzled 9, Wnt3a, LPS, Gut inflammation, Enteric nervous system

\footnotetext{
* Correspondence: rosa.diliddo@unipd.it

${ }^{\dagger}$ Equal contributors

'Department of Pharmaceutical and Pharmacological Sciences, University of

Padova, Via Marzolo 5, 35131 Padova, Italy

Full list of author information is available at the end of the article
} 


\section{Background}

In the last two decades, enormous progress has been made in the characterization of soluble factors that regulate gut functionality at physiological and inflamed conditions. Among signaling molecules, Wnt family proteins (Wnts) are reported to play a pivotal role in the development of gut [1,2] balancing the homeostasis of intestine epithelium [3]. After the binding of Wnt ligands with the $G$ protein-coupled receptor Frizzled (FZD) and single-span low-density lipoprotein receptorrelated protein (LRP) $[4,5], \beta$-catenin is released from the large destruction "scaffolding" complex consisting of Axin, adenomatous polyposis coli (APC), casein kinase 1 (CK1), glycogen synthase kinase $3 \beta$ (GSK3 $\beta$ ) complex, and shuttles to the nucleus promoting the transcription of target genes [http://www.stanford.edu/ rnusse/wntwindow. $\mathrm{html}$. Moreover, under active inhibition induced by GSK3 $\beta$ or cross talked pathways [6-9], $\beta$-catenin is trapped at the plasma membrane or is tagged by phosphorylation for ubiquitin-mediated degradation [10].

Wnt ligands and Frizzled members have been largely studied in animal and human tissues [4,11]. Although the expression of Wnts, Frizzled, and Wnt-Frizzled binding specificities is well defined in epithelial and mesenchymal gut compartments [3], so far they have been poorly investigated in the enteric nervous system (ENS). The control of canonical Wnt pathway on intestinal tract has been first hypothesized observing $\beta$-catenin stabilization in familial and sporadic colon cancers [12]. Furthermore, significant evidences have demonstrated that Wnt ligands control the proliferation, differentiation, and self-renewal of intestinal crypt progenitor cells [13-15], in both paracrine and autocrine fashion [16]. As suggested by the increased expression of Wnts and Frizzled receptors in inflammatory bowel disease (IBD) and ulcerative colitis [17], Wnt signaling is involved in gut inflammation and exerts both anti- and pro-inflammatory functions. In particular, $\beta$-catenin has shown to i) negatively regulate intestinal NF-KB activity in bacterial-induced epithelial inflammation [18], ii) reduce TNFa release [19], and iii) induce the expression of IL1O and TGFB [20] while the activation of proinflammatory mediators seems to be correlated to noncanonical Wnt signaling [21].

The course of Wnt FZD signaling is dictated by the specificity of Wnt-FZD interactions, which is in turn governed by both cell type and stage of development [16,22-24]. Expressed in the dorsal neural tube at the time of neural crest emigration [25], Wnt3a activates $\beta$-catenin target genes that are involved in several processes such as the positioning/maturation of Paneth cells and the proliferation and differentiation of colonic stem cell compartment $[3,26,27]$ but also the maintenance and expansion of enteric neural crest progenitor cells [28]. As the release of Wnt3a increases in response to gut mucosa injury and inflammatory bowel diseases [29-31], the activation of canonical signaling pathway by Wnt3a could be hypothesized as an active mechanism in ENS.

Several studies have reported that Wnts preferentially activate the signaling pathway binding with defined members of FZD family according to a specific tissue distribution. Similarly to other Wnt ligands [32,33], a wide spectrum of FZD binding affinities for Wnt3a has been reported including FZD1 [19], FZD4, FZD5, and FZD8 [34]. Among recently investigated Frizzled receptors, FZD9 has been detected early during the development of the mouse nervous system [35] and this expression pattern is highly conserved like in chicken and zebrafish [36]. When FZD9 is activated by Wnt2, it leads to a Wnt/ $/$-catenin signaling [37]. Although FZD9 is widely expressed on both multipotent neuroepithelial precursor cells and neural-restricted precursors [36,38], it was so far not yet described in the ENS compartment.

Besides Wnt proteins, glial cell-derived neurotrophic factor (GDNF), nerve growth factor (NGF), fibroblast growth factors (FGF), epithelial growth factor (EGF), leukemia inhibitory factor (LIF), interleukin 6 (IL6), and lipopolysaccharide (LPS) from gram-negative enteric bacteria [39-44] modulate strongly the ENS or gut function. In case congenital or acquired defects reduce the bioavailability of enteric neurotrophic factors, a compromised ENS development [45-48] and a dysfunction of the immune system [49] are observed to promote the inhibition of GSK3 $\beta$ activity [50,51] and enterocolitis [52], suggesting that a possible cross talk between $\mathrm{Wnt} / \beta$-catenin pathway and immune response could be involved.

In experimentally LPS-induced colitis, an increased enteric glia activation [53] and neuronal cell death due to an excessive stimulation of excitatory transmitters [54] are reported to occur. The endotoxin LPS is an essential membrane component of luminal microflora bacteria that interacts specifically with enteric responsive cells through toll-like receptor 4 (TLR4) [55-57] to regulate intestinal homeostasis. In neuronal compartments, low-dose LPS can contribute to maintain neuronal survival [58] and differentiation through the activation of NF- $\mathrm{KB}$, while higher doses result in excessive stimulation of proinflammatory cytokines [59] that leads to neuronal toxicity [60]. The involved intracellular signaling cascade includes the phosphorylation of mitogen-activated protein kinase (MAPK) and the migration of NF- $\mathrm{KB}$ into the nucleus [61]. Studies performed on enterocytes [62] showed that the response to LPS triggers the inactivation of GSK3 $\beta$ through the activation of phosphatidylinositol 3 kinase (PI3K)/Akt pathway $[63,64]$. There is increasing evidence that the critical activators of NF- $\mathrm{KB}$ pathway, $\mathrm{IKK} \alpha$, and IKK $\beta$ interact differently with $\beta$-catenin by regulating its protein levels and cellular localization [65]. 
In particular, unlike IKK $\beta$ that is predominantly cytoplasmic and activates NF-кB by phosphorylating ІкBs under proinflammatory stimuli (TNFa, IL1, TLR agonists) [66], IKK $\alpha$ is detected in both nucleus and cytoplasm at resting state and inhibits $\beta$-catenin degradation mediated by Axin/APC/GSK3 $\beta$, as well as it induces cyclin D1 expression that is a point of convergence between the Wnt/ $\beta$ catenin and ІкB pathways in mitogenic signaling [67]. As soon as the IKK complex is activated in response to mitogens, inflammation, apoptosis, immune response, or cancer, IKKa is enhanced to shuttle from cytoplasmic to nuclear compartment where it phosphorylates nuclear p65 within the transactivation domains and promotes the transcriptional activity of NF- $\mathrm{KB}$ target genes. While IKK $\beta$-dependent pathway is essential for activation of innate immunity, IKK $\alpha$-dependent pathway is more important for the regulation of adaptive immunity [66].

Based on these evidences, the present study was focused on the expression and activity of Wnt signaling components such as FZD9 and Wnt3a during the ex vivo growth of postnatal ENS cells. In particular, standard settings and starvation of growth factors were used to simulate physiological and pathological conditions, respectively, as the availability of soluble factors is already demonstrated to control the structural integrity and functionality of ENS. Taking into consideration that canonical Wnt signaling controls stem cell proliferation/differentiation [68-70] and inflammation [71], the immunophenotypical characterization of ENS subpopulations [72], all components of LPS/TLR4 signaling [56] and $\beta$-catenin modulatory activity on NF-кB were explored to better define the ENS response to inflammation [73-75].

\section{Methods}

Isolation of cells from rat enteric nervous system

ENS cells (ENSc) were isolated from Sprague Dawley rats, 3 days old as previously described [76] and under Italian and German ethic committee authorization (CEASA 43/2012). The isolated cells were either cultured in standard (SM) [76] and basal conditions (BM) [Neuronal Base P (PAA, Cölbe, Germany), 1\% L-glutamine (Sigma-Aldrich, St. Louis, MO, USA), 1\% penicillin/ streptomycin (Invitrogen Life Technology, Carlsbad, CA, USA) for 7 days before morphological analysis by optical microscopy, immunophenotypical characterization by flow cytometry (FCM) and Wnt signaling study by gene expression, Western blotting (WB), protein complex immunoprecipitation (Co-IP), and immunofluorescence assay (IF) were performed.

\section{Immunophenotype characterization by FCM}

The analysis was performed on ENSc at time of isolation (T0) and after 7-day culture (T7) using the primary antibodies reported in Table 1. In parallel, controls were
Table 1 Primary and secondary antibodies used for the immunophenotypical characterization of ENS cells

\begin{tabular}{ll}
\hline Primary antibodies & Manufacturing company \\
\hline Mouse anti-rat NG2 FITC & Santa Cruz Biotechnology, Inc \\
Goat anti-rat Nanog PE & BD Biosciences \\
Mouse anti-rat CD34 PECy7 & BD Biosciences \\
Rabbit anti-rat Sox2 & Millipore \\
Rabbit anti-rat Sox10 & Santa Cruz Biotechnology, Inc \\
Rabbit anti-rat TLR4 & Santa Cruz Biotechnology, Inc \\
Goat anti-rat Frizzled 9 & Santa Cruz Biotechnology, Inc \\
Mouse anti-rat Nestin & Millipore \\
Mouse anti-rat GFAP & Millipore \\
Mouse anti-rat PAN neuronal & Millipore \\
Rabbit anti-rat p75 & Millipore \\
Secondary antibodies & \\
Goat anti-mouse FITC & \\
Goat anti-rabbit FITC & Santa Cruz Biotechnology, Inc \\
Bovine anti-goat FITC & Santa Cruz Biotechnology, Inc \\
Donkey anti-goat PE & Santa Cruz Biotechnology, Inc \\
\hline
\end{tabular}

stained using only corresponding secondary or isotypic antibodies. Data were acquired using FACSCanto II Flow cytometer (BD Biosciences, San Josè, CA, USA) and FACSDiva v6.1.3 software (BD Biosciences). The positive expression of each target marker was established using the overton subtraction tool of Summit 4.3 software (Beckman Coulter Inc, Brea, CA, USA).

\section{Immunofluorescence analysis}

ENS cells cultured for 7 days (T7) in SM or BM were fixed with BD Cytofix solution (BD Biosciences), for 20 $\mathrm{min}$, at $4^{\circ} \mathrm{C}$. All samples were double stained with primary goat anti-rat Frizzled 9 or rabbit anti-rat TLR4 (Santa Cruz Biotechnology, Inc, Dallas, TX, USA) and, then, indirectly conjugated with PE and FITC secondary antibodies (Santa Cruz Biotechnology, Inc), respectively. In parallel, single staining with primary rabbit anti-rat Wnt3a (Cell Signaling Technology, Inc, Danvers, MA, USA) and FITC-conjugated secondary antibody was performed. As negative controls, specimens stained only with FITC- and PE-conjugated secondary antibodies were prepared. After mounting with Fluoro-Gel II solution containing DAPI (EMS, Hatfield, PA, USA), the samples were analyzed using a Leica TCS SP5 confocal microscope (Leica, Wetzlar, Germany).

\section{Formation of neurospheres under Wnt3a and LPS treatment}

ENS cells were seeded at $16 \times 10^{3} / \mathrm{cm}^{2}$ and cultured for 14 days with or w/o $5 \mu \mathrm{g} / \mathrm{mL}$ LPS (Sigma-Aldrich) or 20 ng/mL Wnt3a (R\&D System, Minneapolis, MN, USA). 
After 1 (T1), 7 (T7), and 14 (T14) days, the number of neurospheres was counted using an Olympus CKX 41 microscope (Olympus, Hamburg, Germany) equipped with a Moticam 2500 and Motic Images Plus 2.0 software (Motic, Wetzlar, Germany). In parallel, the diameter of neurospheres was measured using the image processing software Image).

\section{Wnt and LPS/TLR4 signaling pathway investigation}

To investigate a possible interplay between Wnt and PI3K/Akt signaling pathways in ENSc, nuclear and cytoplasmic proteins were extracted from samples cultured in $\mathrm{SM}$ and $\mathrm{BM}$ and treated for $30 \mathrm{~min}, 1 \mathrm{~h}$, and $2 \mathrm{~h}$ with $5 \mu \mathrm{g} / \mathrm{mL}$ LPS or $20 \mathrm{ng} / \mathrm{mL}$ Wnt3a. Proteins were obtained using NER PER Nuclear and Cytoplasmic Extraction Reagents kit and then quantified with BCA Protein Assay Reagent Kit (Thermo Fisher Scientific, Waltham, MA, USA) according to the manufacturer's protocols. The separation of proteins was assessed by SDS/PAGE (Bio-Rad Laboratories, Inc, Hercules, CA, USA), and the immunoblot was carried out by overnight incubation, at $4^{\circ} \mathrm{C}$, with primary rabbit anti-rat $\mathrm{p}(\mathrm{Ser} 9)$-GSK3 $\beta$ (Cell Signaling Technology, Inc), mouse anti-rat $\mathrm{p}(\mathrm{Ser} 473)$-Akt, $\beta$-catenin, $p($ Ser33)- $\beta$-catenin, NF- $\kappa B$ p50, and rabbit antirat NF-кB p65 (Santa Cruz Biotechnology, Inc) antibodies. The detection of target proteins was performed using peroxidase-conjugated goat anti-rabbit and goat antimouse secondary antibodies (Bio-Rad Laboratories, Inc). The development of immunoreactivity was enhanced by chemiluminescence substrate (ECL) (Sigma-Aldrich) and then visualized by VersaDoc Imaging System. The protein expression level was normalized to housekeeping protein GAPDH (Millipore) or lamin B (Santa Cruz Biotechnology, Inc) and quantified using the image processing software ImageJ. Data were reported as ratio within target protein and relative housekeeping protein expression.

\section{Co-IP: Wnt3a/Frizzled 9 (A) and NF-kB p65/ $\beta$-catenin (B) binding assay}

Total nuclear proteins were extracted from ENS cells cultured for 7 days (T7) using RIPA lysis buffer. (A) Recombinant Wnt3a protein (R\&D System, Minneapolis, MN, USA) was added (200 $\mathrm{ng} / \mathrm{mL})$ to protein extracts and incubated overnight at $4^{\circ} \mathrm{C}$. The immunoaffinity purification was performed as previously reported [77], using goat antirat Frizzled 9 (Santa Cruz Biotechnology, Inc) and rabbit anti-rat Wnt3a (Cell Signaling Technology, Inc) preimmobilized onto Protein A Sepharose (Sigma-Aldrich). Western blot analysis was carried out using 4\%-15\% Mini PROTEAN $^{\circ}$ TGXTM Precast Gel (Bio-Rad Laboratories, Inc, Milan, Italy) and goat anti-rat Frizzled 9 (Santa Cruz Biotechnology, Inc) or rabbit anti-rat Wnt3a (Cell Signaling Technology, Inc). (B) For NF- $k B$ p65/ $\beta$-catenin binding assay, the immunoaffinity purification was performed using rabbit anti-rat NF-kB p65 or mouse anti-rat $\beta$-catenin (Santa Cruz Biotechnology, Inc), pre-immobilized onto Protein A Sepharose (Sigma-Aldrich). Both antibodies were used for Western blot analysis by $6.5 \%$ polyacrylamide gel (Bio-Rad Laboratories, Inc).

\section{Gene expression study: RT-PCR and qPCR}

At 1 (T1) and 7 (T7) days from stimulation with Wnt3a and LPS, total cellular RNA was extracted using TRIzol $^{\circ}$ (Invitrogen Life Technology), quantified by measuring the absorbance at $260 \mathrm{~nm}$ and then stored at $-80^{\circ} \mathrm{C}$ until use. Ten nanogram of RNA were reverse transcribed and amplified using Qiagen One Step RT-PCR Kit (Qiagen, Hilden, Germany) and an iCycler iQ ${ }^{\text {rit }}$ (Bio-Rad Laboratories, Inc). Primer pairs for target and housekeeping genes were designed as reported in Table 2 and purchased from Invitrogen Life Technology. RT-PCR products were electrophoresed on a $2 \%$ agarose gel (Invitrogen Life Technology) stained with GelRed ${ }^{\text {Tum }}$ (Biotium, Inc, Hayward, CA, USA) and visualized using a UV transilluminator Gel Doc 2000 Gel Documentation System (Bio-Rad Laboratories, Inc). For genes reported in Table 3, the analysis was conducted by qPCR. In particular, the reverse transcription reaction was done with Thermoscript ${ }^{\text {tw }}$ RT-PCR System kit (Invitrogen Life Technology) and iCycler $\mathrm{iQ}^{\mathrm{m}}$ while the amplification reaction was carried out using Platinum $^{\circ}$ SYBR $^{\circ}$ Green qPCR SuperMix UDG kit (Invitrogen Life Technology) and a DNA Engine Opticon ${ }^{\circ}$ Real Time Thermal Cycler (MJ Research, St. Bruno, QC, Canada). The amount of gene products was calculated using linear regression analysis from standard curves, demonstrating amplification efficiencies ranging from $95 \%$ to $100 \%$. Data were reported as a fold increase of gene expression that is defined as the complementary DNA (cDNA) ratio between target gene and reference gene (HPRT) normalized to untreated sample. Statistical significance was calculated by Student's $t$-test comparing to untreated samples: $p$ value $\leq 0.05^{*}, p$ value $\leq 0.01^{* *}$; samples compared to LPS-treated cells: $p$ value $\leq 0.01$ (two black triangles).

\section{Results}

\section{Growth factors modulate the expression of FZD9 and TLR4 positive cells}

By flow cytometric analysis, freshly isolated ENSc showed a heterogeneous immunophenotype with a specific stemness pattern (Figure 1A), as suggested at T0 by the expression of Nanog (26.9 $\pm 0.6 \%)$, Sox2 (64.9 $\pm 1.4 \%)$, Sox10 (17.7 $\pm 0.4 \%)$, and p75 (55.0 $\pm 3.2 \%)$. Multidifferentiative potential of freshly isolated rat ENS cells was confirmed by the expression of nerve/glial antigen 2 (NG2) $(51.9 \pm 4.3 \%)$, a proteoglycan typically observed on the membrane of multipotent neural stem cells. Moreover, the presence of nestin $(24.0 \pm 3.3 \%)$ and CD34 $(35.9 \pm 1.2 \%)$ 
Table 2 Primer sequences for One-Step RT-PCR analysis

\begin{tabular}{|c|c|c|c|}
\hline Gene & Abbreviations & Primer sequences & Accession \\
\hline \multirow[t]{2}{*}{ Glial cell-derived neurotrophic factor } & GDNF & F: CCAGAGAATTCCAGAGGGAAAG & NM_019139.1 \\
\hline & & R: CTTCACAGGAACCGCTACAA & \\
\hline \multirow[t]{2}{*}{ Epidermal growth factor } & $E G F$ & F: GGGCTATCCCATCGGTAATAAG & NM_012842.1 \\
\hline & & R: CAGCCTCCATTCCTGTGTAA & \\
\hline \multirow[t]{2}{*}{ Basic fibroblast growth factor } & BFGF & F: AGAGGAGTTGTGTCCATCAAG & NM_019305.2 \\
\hline & & R: CTCCAGGCGTTCAAAGAAGA & \\
\hline \multirow[t]{2}{*}{ Nerve growth factor } & NGF & F: CAGTGTGTGGGTTGGAGATAA & NM_001277055.1 \\
\hline & & R: GCATCCACTCTCTACAGGATTC & \\
\hline \multirow[t]{2}{*}{ Leukemia inhibitory factor } & LIF & F: TGACGGATTTCCCACCTTTC & NM_022196.2 \\
\hline & & R: CGTCTGTAGTCGCATTGAGTT & \\
\hline \multirow[t]{2}{*}{ Hypoxanthine-guanine phosphoribosyltransferase } & HPRT & F: GCTGACCTGCTGGATTACAT & NM_012583.2 \\
\hline & & R: CCCGTTGACTGGTCATTACA & \\
\hline
\end{tabular}

$F$ forward, $R$ reverse.

combined with the absence of cKit and CD44 (data not shown) was correlated to the presence of an immature cell population including neural precursors. The presence of differentiated glial and neuronal cells was revealed by the expression of GFAP $(22.5 \pm 0.6 \%)$ and PAN neuronal $(42.1 \pm 1.8 \%)$, respectively. The detection of Frizzled 9
$(17.5 \pm 3.0 \%)$ was indicative of constitutive activity of Wnt signaling while the responsiveness of ENS populations to LPS stimulus was suggested by the expression of TLR4 receptor $(19.5 \pm 0.7 \%)$. After 7 days of culture, a different expression level of stem cell markers was observed in samples treated under simulated physiological $(\mathrm{SM})$ and

Table 3 Primer sequences for qPCR analysis

\begin{tabular}{|c|c|c|c|}
\hline Gene & Abbreviations & Primer sequences & Accession \\
\hline \multirow[t]{2}{*}{ Toll-like receptor 4} & TLR4 & F: ATTGCTCAGACATGGCAGTTC & NM_019178.1 \\
\hline & & R: CACTCGAGGTAGGTGTTTCTGCTAA & \\
\hline \multirow[t]{2}{*}{ Wingless type MMTV integration site family, member $3 \mathrm{~A}$} & WNT3A & F: TGCAAATGCCACGGACTATC & NM_001107005.2 \\
\hline & & R: AGACTCTCGGTGTITCTCTACC & \\
\hline \multirow[t]{2}{*}{ Frizzled 9} & FZD9 & F: TACCCAGAGCGCCCTATAAT & NM_153305.1 \\
\hline & & R: CAAACCCTCCTGGATCACATAC & \\
\hline \multirow[t]{2}{*}{ Axis inhibition protein 2} & AXIN2 & F: ACCTATGCCTGTCTCCTCTAAC & NM_024355.1 \\
\hline & & R: GTCCAGGGTATCCACACATTTC & \\
\hline \multirow[t]{2}{*}{ Myelocytomatosis proto-oncogene } & CMYC & F: CTTGGAACGTCAGAGGAGAAA & NM_012603.2 \\
\hline & & R: GCTTGAACGGACAGGATGTA & \\
\hline \multirow[t]{2}{*}{ Jun proto-oncogene } & CJUN & F: GAAGCAGAGCATGACCTTGA & NM_021835.3 \\
\hline & & R: CCATTGCTGGACTGGATGAT & \\
\hline \multirow[t]{2}{*}{ Interleukin-1 $\beta$} & $\| 1 B$ & F: AGTGAGGAGAATGACCTGTTC & NM_031512.2 \\
\hline & & R: CGAGATGCTGCTGTGAGATT & \\
\hline \multirow[t]{2}{*}{ Interleukin-6 } & IL6 & F: GCCAGAGTCATTCAGAGCAATA & NM_26744.1 \\
\hline & & R: GTTGGATGGTCTTGGTCCTTAG & \\
\hline \multirow[t]{2}{*}{ Interleukin-10 } & 1410 & F: ATTGAACCACCCGGCATCTA & NM_012854 \\
\hline & & R: CAACGAGGTITCCAAGGAG & \\
\hline \multirow[t]{2}{*}{ Tumor necrosis factor a } & TNFa & F: GCAGATGGGCTGTACCTTATC & NM_012675.3 \\
\hline & & R: GGCTGACTITCTCCTGGTATG & \\
\hline \multirow[t]{2}{*}{ Hypoxanthine-guanine phosphoribosyltransferase } & HPRT & F: GCTGACCTGCTGGATTACAT & NM_012583.2 \\
\hline & & R: CCCGTTGACTGGTCATTACA & \\
\hline
\end{tabular}




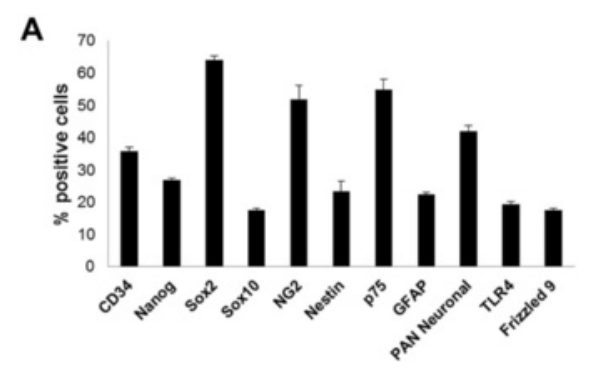

B

CD34
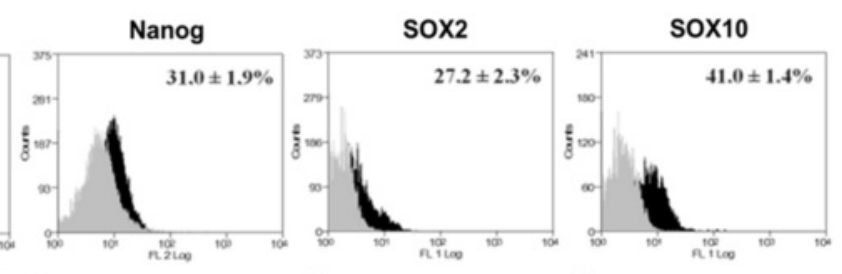

BM
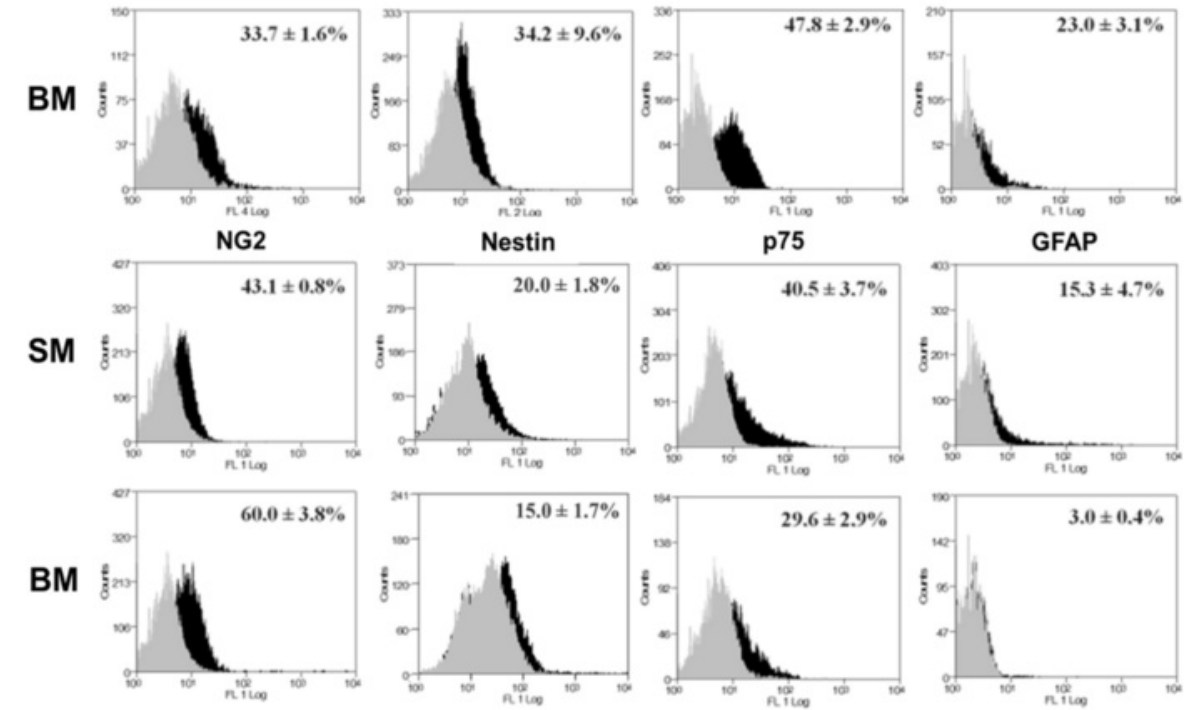

C

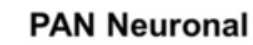

Frizzled 9

\section{TLR4}
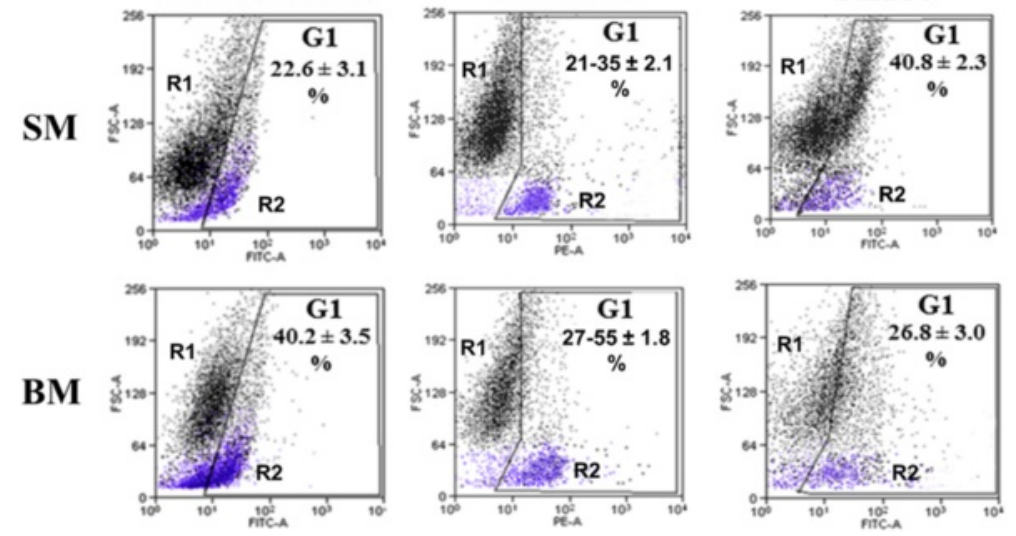

Figure 1 (See legend on next page.) 
(See figure on previous page.)

Figure 1 FCM analysis of ENSc at T0 and T7. (A) As reported by FCM analysis, freshly isolated ENSC (T0) resulted as a heterogeneous population including stem-like, progenitor, glial, and neuronal cells. For each experimental condition, $10^{4}$ cells were used for acquisition by FACSCanto II and data were expressed as percentage (\%) of positive cells \pm standard deviation (SD) where each marker was compared to control samples stained only with isotype or secondary control antibody. The positive expression was quantified using the overton subtraction tool of Summit 4.3 software (Beckman Coulter Inc). Under SM and BM culture conditions, the aspecific modulation of glial and neuronal differentiation was detected. (B) Immunophenotypical characterization by FCM of ENSc cultured for 7 days (T7). Data were expressed as percentage (\%) of positives (black profile) \pm SD for each marker compared to corresponding staining control (gray profile). (C) FCM analysis of PAN neuronal, Frizzled 9, and TLR4 expression. Data were reported as FSC vs fluorescent marker dot plot where R1 (blue colored) and R2 (black colored) subsets were defined. The positive expression of each target marker \pm SD was discriminated in gate G1 defined with respect to staining control.

reduced conditions (BM) (Figure 1B). As previously reported, Sox2 showed to be downregulated in cells maintained in SM $(27.2 \pm 2.3 \%)$ and in BM $(47.8 \pm 2.9 \%)$. In contrast, a significant increase of positivity for the pluripotency marker Nanog $(31.0 \pm 1.9 \%$ in SM; $34.2 \pm 9.6 \%$ in $\mathrm{BM})$, Sox10 (41.0 $\pm 1.4 \%$ in SM; $23.0 \pm 3.1 \%$ in BM), and p75 (40.5 $\pm 3.7 \%$ in SM; $29.6 \pm 2.9 \%$ in BM) was detected. Although unchanged in SM (15.3 $\pm 4.7 \%)$, a significant decrease of GFAP expression was detected in samples under basal conditions $(3.0 \pm 0.4 \%)$. No significant alterations of CD34 (31.3 $\pm 1.3 \%$ in SM; $33.7 \pm 1.6 \%$ in BM) and nestin $(20.0 \pm 1.8 \%$ in $\mathrm{SM} ; 15.0 \pm 1.7 \%$ in $\mathrm{BM})$ level expression were identified. Characterized by the expression of PAN neuronal antigen and lower FSC value in FCM dot plots (Figure 1C, blue-colored R2 subset), the neuronal subpopulation increased significantly in BM $(40.2 \pm 3.5 \%)$ with respect to SM-treated samples $(22.6 \pm 3.1 \%)$. Interestingly, the expression of Frizzled 9 (21-35 $\pm 2.1 \%$ in SM; 27-55 $\pm 1.8 \%$ in $\mathrm{BM})$ was restricted in neuronal population (Figure 1C, blue-colored R2 subset). In contrast, a FCM biparametrical analysis (FSC vs TLR4) showed that TLR4 was distributed either in neurons and glial subpopulation (Figure 1C, black-colored R1 subset) with higher expression in SM $(40.8 \pm 2.3 \%)$ compared to BM $(26.8 \pm 3.0 \%)$.

\section{Frizzled 9 is coexpressed with TLR4 in enteric neurons}

By immunofluorescence staining, TLR4 and Frizzled 9 were confirmed to be coexpressed only in the neuronal subset (Figure 2A, arrows). When Co-IP was performed to investigate whether Frizzled 9 mediates canonical Wnt signaling, we evidenced a $107 \mathrm{kDa}$ band corresponding by molecular weight to Wnt3a/Frizzled 9 complex (Figure 2B) suggesting that Wnt3a could interact in vivo with Frizzled 9 and promote the activation of canonical Wnt signaling. Moreover, as cytoplasmic immunoreactivity for Wnt3a antibody was observed only in glial cells, a specific regulation of neuronal reactivity was hypothesized to be controlled by enteric glia by canonical Wnt (Figure 2C).

Wnt3a and LPS enhance the proliferation of neurospheres ENS-derived cells are usually cultured in vitro as aggregates known neurospheres that, including proliferating progenitors, neurons, and glial cells, mimic the in vivo niche of the gut. As growth factors and neurotrophic stimuli are demonstrated to be essential under in vivo settings for ENS functionality, they were used to study the regulation by Wnt signaling on the proliferation/ differentiation of ENS cells under physiological conditions.

Typical neurospheres were detected by optical microscopy in ENS samples cultured in standard medium (Figure 3A). From 1 (T1) to 14 (T14) days of culture, LPS $(5 \mu \mathrm{g} / \mathrm{mL})$ and Wnt3a $(20 \mathrm{ng} / \mathrm{mL})$ demonstrated to induce in SM a significant $(p \leq 0.05 \%)$ increased number of neurospheres with higher extent in LPS-treated samples (Figure 3B,C). In parallel (Figure 3D), an enhanced proliferation rate was indirectly evaluated measuring the neurosphere diameter that resulted to be changed in control samples from 33 (T1) to $54 \mu \mathrm{m}$ (T14) while in Wnt3a and LPS-treated samples increased from 43 (T1) to $75 \mu \mathrm{m}$ (T14) and from 41 (T1) to $62 \mu \mathrm{m}$ (T14), respectively. No neurosphere formation but several fibroblastoid colonies were observed in ENSc cultured in BM. These evidences suggested that the formation of neurospheres was strictly depending on growth factor stimulation.

\section{Canonical Wnt pathway is active in ENS cells and is modulated by growth factors}

When the in vivo availability of soluble factors is restricted, the structural integrity of ENS is compromised with following inflammatory diseases. Using restricted culture conditions simulating a pathological disorder, we better defined the ENS response to inflammation.

Both canonical pathway of Wnt signaling and LPS/ TLR4 pathway play important roles in controlling the plasticity of ENS. Specific phosphorylation events control the active state of Akt [p(Ser473)-Akt], deactivate GSK3 $\beta$ [p(Ser9)-GSK3 $\beta$ ], and tag $\beta$-catenin for proteosomal degradation [p(Ser33)- $\beta$-catenin]. In order to evaluate a cross talk between Wnt and NF-кB pathways, a protein expression analysis by WB was carried out to evaluate the phosphorylated state of Akt, GSK3 $\beta, \beta$ catenin, and the nuclear translocation of both $\beta$-catenin (n- $\beta$-catenin) and NF-кB (n-NF-кB р65, n-NF-кB р50) (Figure 4). As phosphorylation events and cytoplasmic 


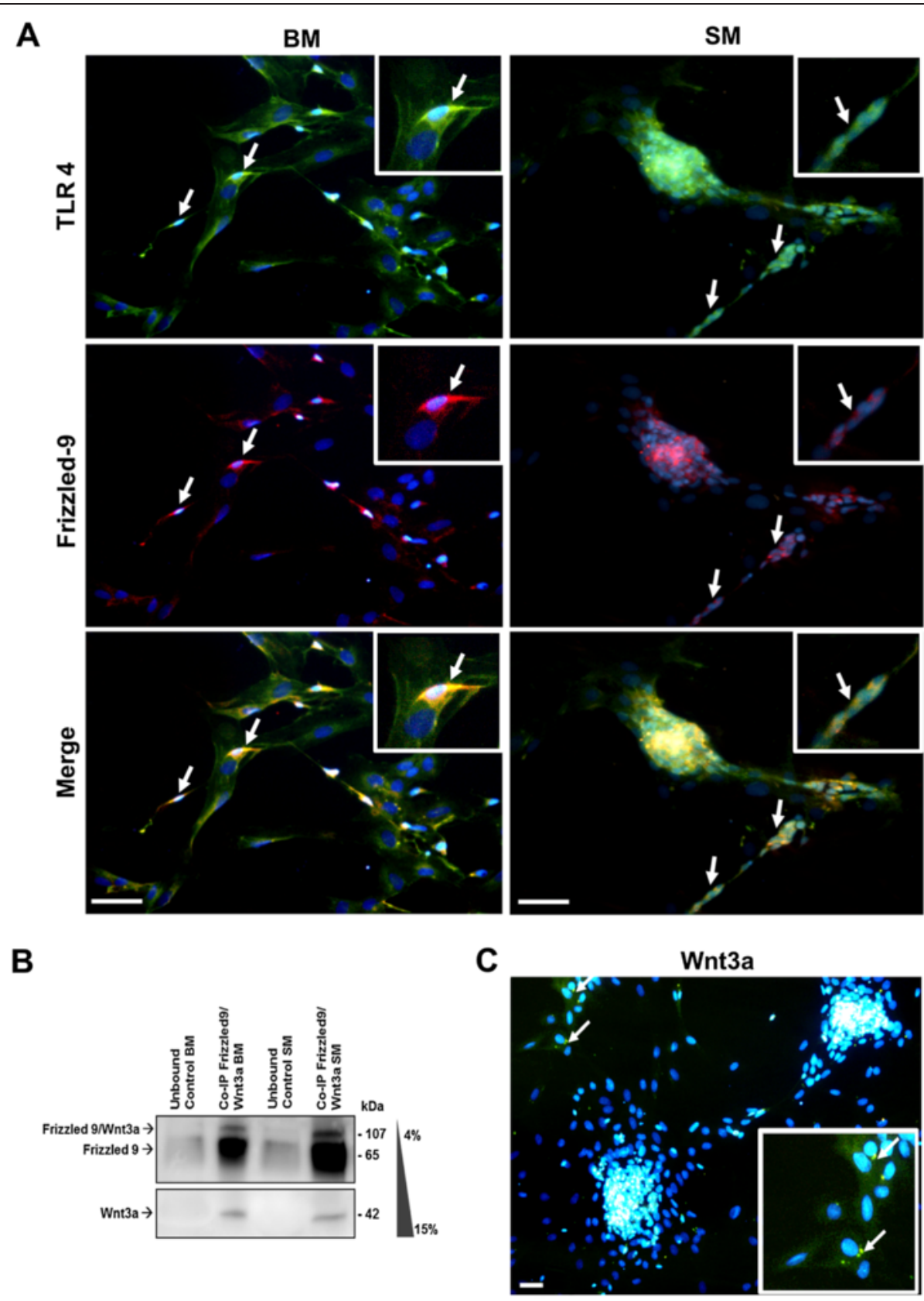

Figure 2 IF analysis of TLR4 and Frizzled 9. (A) Confocal microscopy analysis evidenced the coexpression of TLR4 and Frizzled 9 on neuronal cells (arrows) either in SM- than BM-treated samples. (B) Co-immunoprecipitation was performed on total protein extracts from ENSc cultured for 7 days in SM or BM. Immunoaffinity purification was carried out using goat anti-rat Frizzled 9 and rabbit anti-rat Wnt3a antibodies pre-immobilized onto Protein A Sepharose. Western blot analysis was assessed using 4\%-15\% gradient precast polyacrylamide gel. (C) By immunofluorescence assay, ENSC showed cytoplasmic vesicles immunoreactive (arrows) to rabbit anti-rat Wnt3a antibody. Bar: $15 \mu \mathrm{m}$.

nucleus shuttling of transcription factors are very fast processes, WB analysis was performed using a time course ranging from 0 (T0) to $2 \mathrm{~h}$ (T2h) from start of stimulation. As shown in Figure 4A, an important modulation by supplemented growth factors was active on Wnt and LPS pathways involving the inactivation of
GSK3 $\beta$ through its phosphorylation at Ser9 and the unmasking of cytoplasmic NF- $\mathrm{KB}$, respectively. Moreover, the presence of nuclear $\beta$-catenin suggested that Wnt signal escaped from negative regulation in cytoplasmic compartment. Without any specific induction of Wnt or NF-KB signaling and under starvation of growth factors 


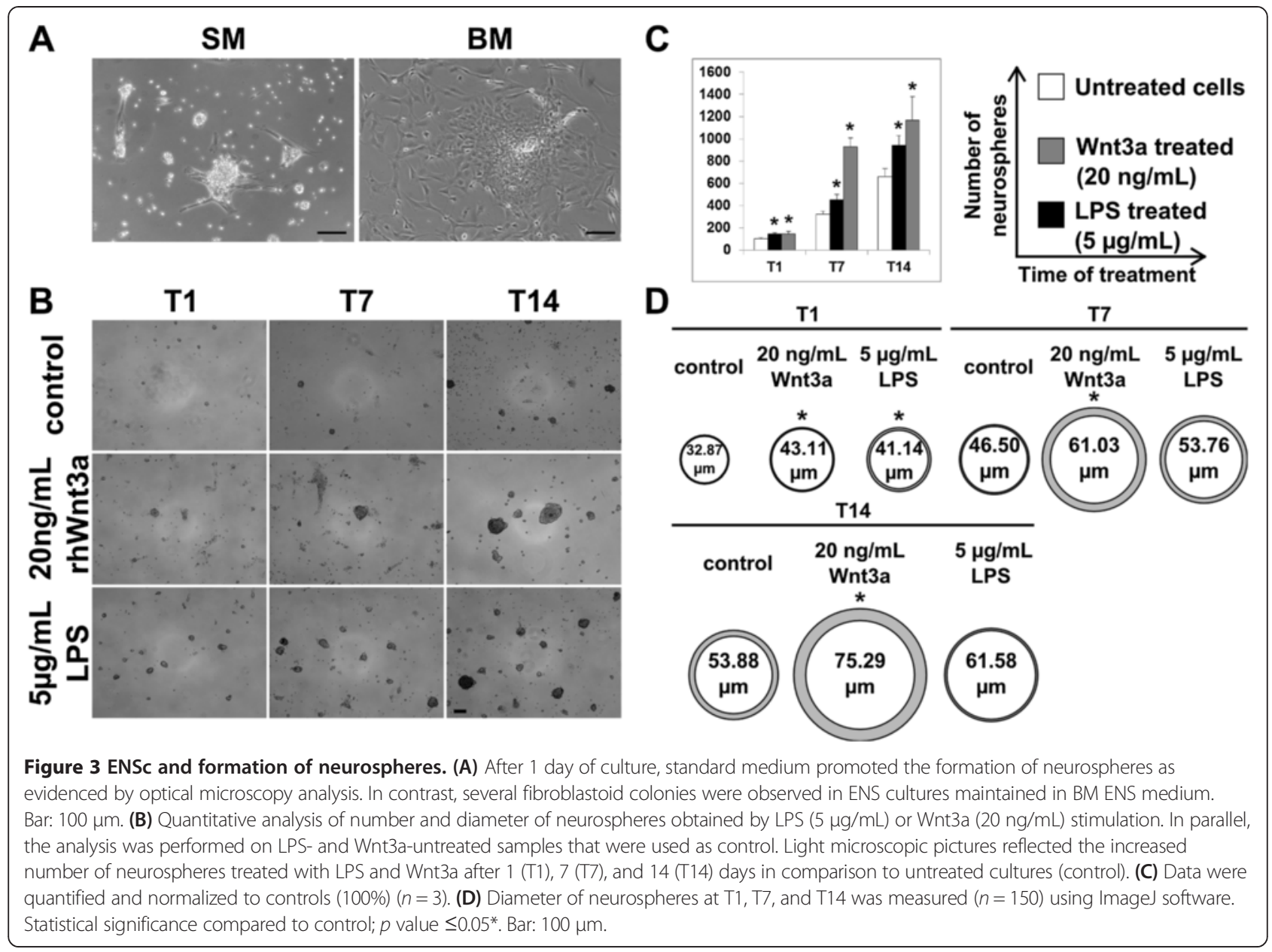

(BM), at T0 we observed that Akt was unphosphorylated, GSK3 $\beta$ was active, and the nuclear localization of $\beta$-catenin and NF-кB p65 was undetectable (Figure 4A). However, after $30 \mathrm{~min}$ from stimulation, pAkt was effective to contrast the negative regulation induced by GSK3 $\beta$ as demonstrated by the presence of $\beta$-catenin only in the nucleus together with NF-кB p65. The cytoplasmic level of $\beta$-catenin is controlled by Akt and GSK3 $\beta$ by phosphorylation tagging that, in our study, was interestingly increased when active Akt was more expressed (T1h, T2h) (Figure 4A). The lacking phosphorylation of GSK3 $\beta$ at Ser9 in BM-treated samples confirmed that PI3K stimulation by growth factors cross talks with Wnt signaling, as previously reported [6].

BM conditions showed to specifically discriminate the effects of Wnt3a and LPS on ENS cells. Similar expression profiles of $\beta$-catenin, Akt, and GSK3 $\beta$ were observed in samples treated with Wnt3a and LPS (Figure 4B,C) suggesting an interplay between Wnt and NF- $\mathrm{kB}$ pathways. In fact, in both cases, the activation of Wnt signal involved the phosphorylation of GSK3 $\beta$ at
Ser9, the nuclear translocation of $\beta$-catenin and NF-kB p65, and the phosphorylation tagging of $\beta$-catenin only at early phase of stimulation (T30').

\section{Wnt3a interferes with inflammatory ENS response}

As expected, NF-kB p50/p65 heterodimer was detected in the nuclear compartment at early phase of stimulation with LPS (T30') (Figure 5A). Interestingly, the presence of p65 subunit was observed in all other experimental conditions but not at T0 in BM suggesting that Wnt signaling interfered with canonical NF-kB pathway [78]. Moreover, we hypothesized that, due to alternative regulatory mechanisms, a possible specific stimulus-independent p65 translocation occurred [67,78]. In parallel, Co-IP assay demonstrated that NF- $\mathrm{KB}$ p65 was present in the nucleus both as free protein and $\beta$-catenin/p65 complex (Figure 5B). As $\beta$-catenin showed a similar conformation pattern, our data confirmed the hypothesis of a nuclear regulation of Wnt signaling on LPS/NF-кB pathway [67]. Unlikely BMtreated cultures, ENSc showed in SM an enhanced 


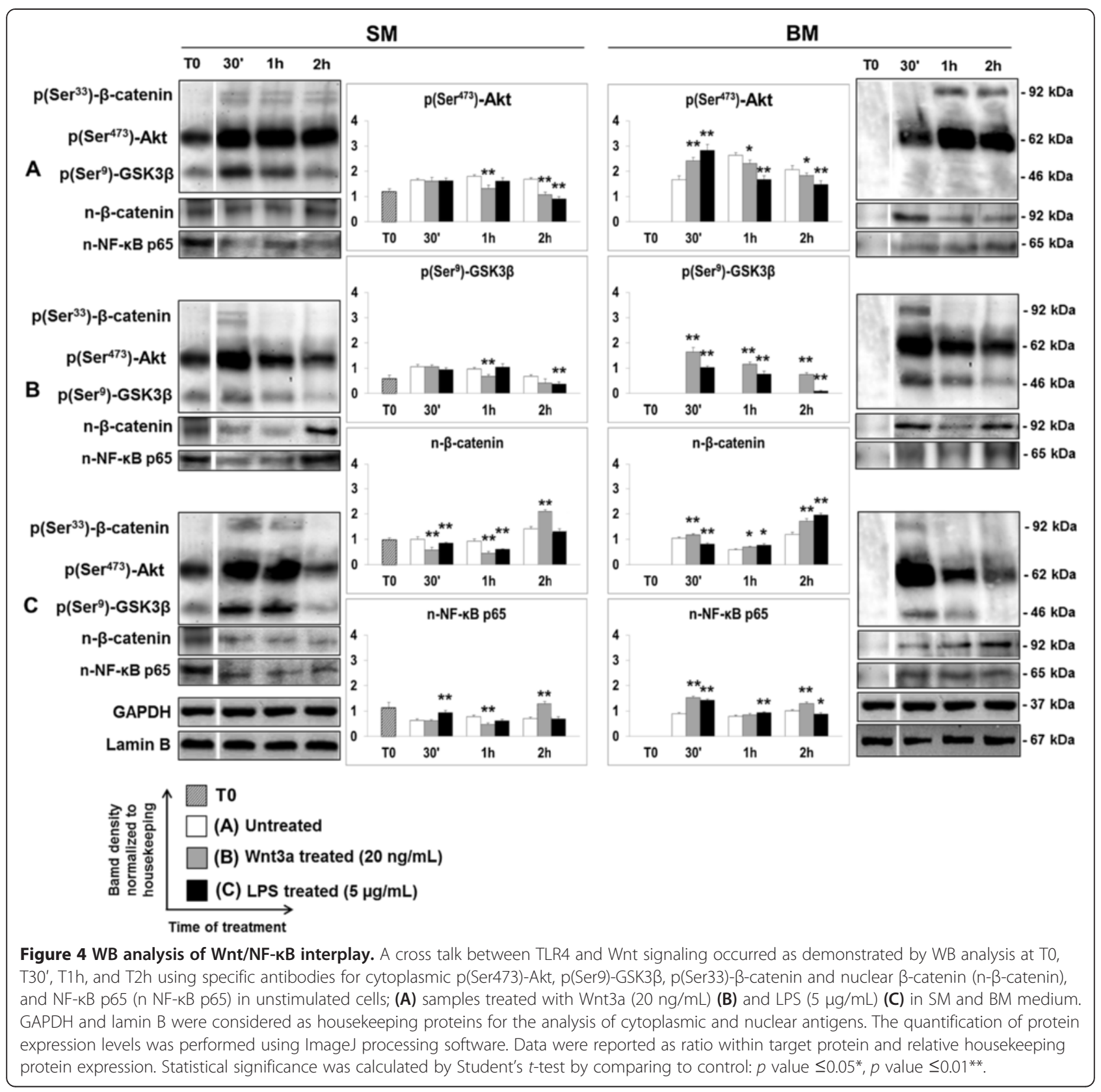

formation of the $\beta$-catenin/p65 complex with respect to free protein fraction.

\section{Exogenous Wnt3a exerts anti-inflammatory activity on ENSC}

As suggested by RT-PCR (Figure 6B), a constitutive expression of GDNF, $E G F$, basic fibroblast growth factor $(B F G F), N G F$, and LIF was observed in all samples without any significant modulation by culture conditions and stimulation. These evidences highlighted that ENSc might modulate their reactivity to exogenous Wnt3a and LPS at longer time of culture (T7) through an endogenous production of growth factors. For this reason, in our opinion, the specific effect of Wnt3a and LPS could be really discriminated at early time of stimulation (T1). As AXIN2, CJUN and CMYC are reported as target genes of $\beta$ catenin transcriptional activity, their expression $(p \leq 0.01)$ at $\mathrm{T} 1$ (Figure 6A) was considered dependent on the specific activation of Wnt signaling in comparison to control. LPS treatment enhanced $(p \leq 0.05)$ the gene expression of FZD 9 and WNT3A $(p \leq 0.01)$ while decreased $(p \leq 0.05)$ the mRNA level of TLR4. Specific LPS-mediated response showed an increased expression $(p \leq 0.05)$ of TNFa, IL6, and $I L 1 B$ genes while a reduced level $(p \leq 0.05)$ of IL10 mRNA was observed. The costimulation with LPS and Wnt3a reversed the expression pattern of ENSc 


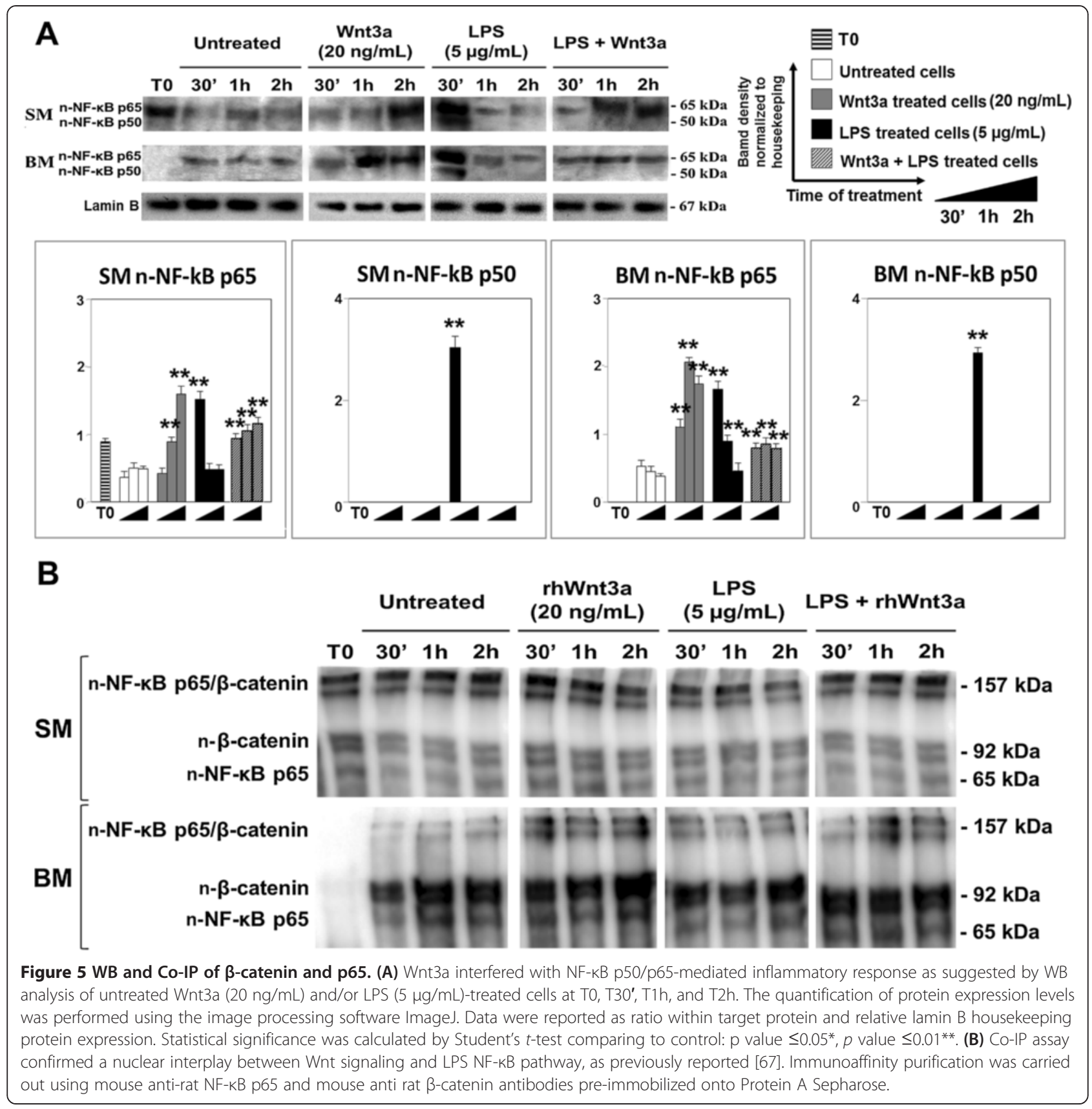

$(p \leq 0.01)$. Moreover, Wnt3a demonstrated to exert a negative control $(p \leq 0.01)$ on the gene expression of proinflammatory cytokines and to enhance ENS defense promoting an increased expression of anti-inflammatory IL1O $(p \leq 0.01)$ and FZD9 $(p \leq 0.01)$. Probably due to a feedback loop aimed to restore homeostatic conditions, TLR4 expression was increased by Wnt3a $(p \leq 0.05)$ (Figure 6A).

\section{Discussion}

When intestinal homeostasis [23] is disrupted by severe inflammation, pathologic changes of ENS neurons [79-81] and glial cells [82] occur, compromising gut motility and secretion $[73,82,83]$. In concentration-dependent manner [60], LPS contributes to ENS plasticity [84] and targets enteric neuronal and glial populations through TLR4 $[85,86]$ promoting the secretion of pro- and anti-inflammatory effectors $[87,88]$. Recently, higher gene expression of Wnt3a and FZD9 has been demonstrated in IBD disorders in comparison to healthy patients [31] suggesting the involvement of canonical Wnt signaling into gut inflammatory response.

The current study identified rat FZD9 as a novel marker associated with rat myenteric plexus and its ability to respond to Wnt3a ligand activating $\beta$-catenin 


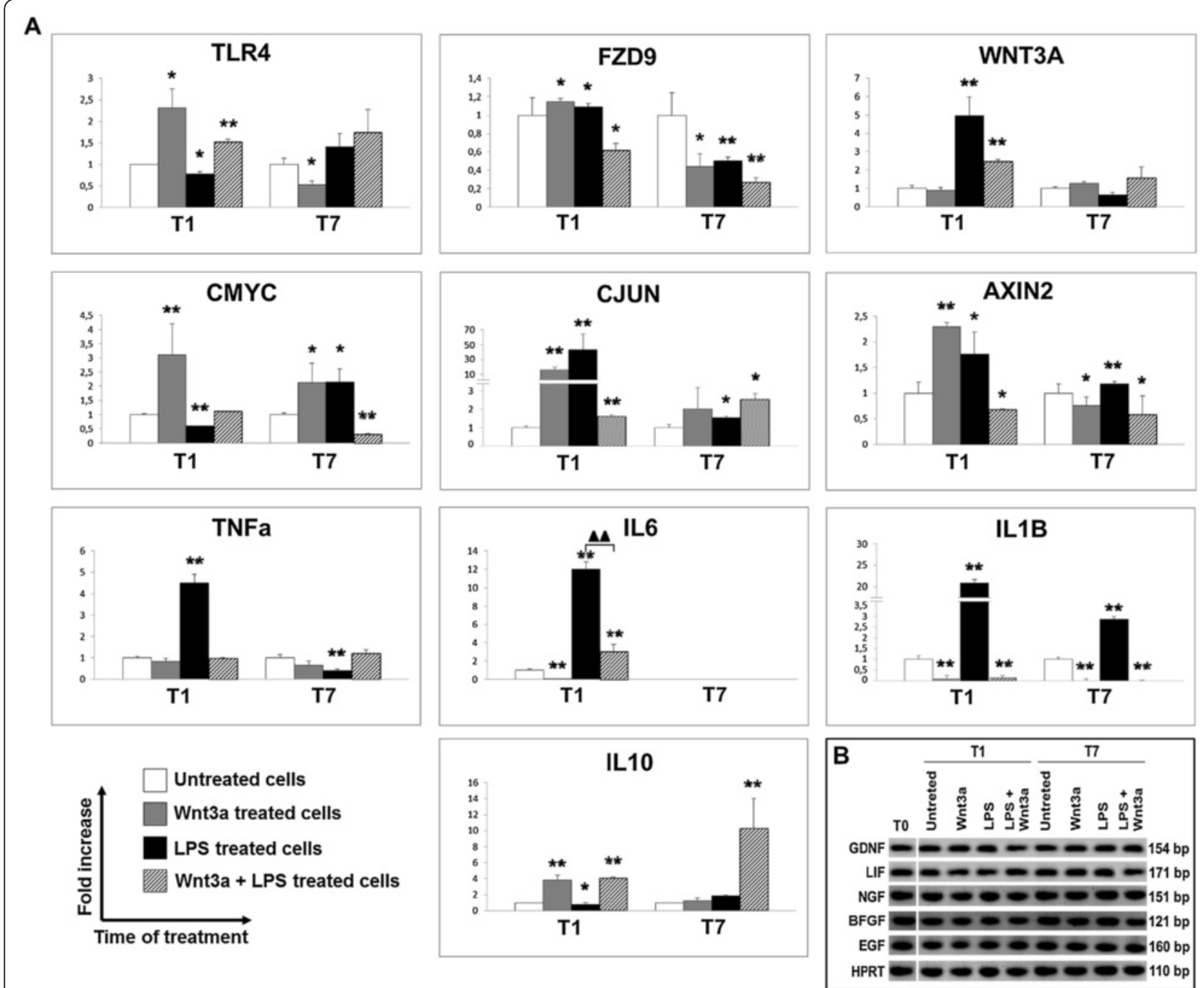

Figure 6 Gene expression study on ENSc stimulated with Wnt3a and LPS. (A) The anti-inflammatory effect was demonstrated to be exerted by Wnt3a using qPCR analysis and ENS cells treated with Wnt3a $(20 \mathrm{ng} / \mathrm{mL})$ and LPS $(5 \mu \mathrm{g} / \mathrm{mL})$. The analysis was focused on the expression of $\beta$-catenin target genes (AXIN2, CMYC, and CJUN), membrane receptors (TLR4 and FZD9), Wnt3a ligand, and pro- and anti-inflammatory target genes $(I L I B, I L 6, T N F a$, and IL10). The amount of gene products was calculated using linear regression analysis from standard curves, demonstrating the amplification efficiencies ranging from $90 \%$ to $100 \%$. Data were reported as a fold increase of gene expression that is defined as the cDNA ratio between target gene and reference gene (HPRT) normalized to untreated sample. Statistical significance was calculated using Student's $t$-test, comparing to untreated cells: $p$ value $\leq 0.05^{*}, p$ value $\leq 0.01^{* *}$; samples compared to LPS-treated cells: $p$ value $\leq 0.01$ (two black triangles). (B) To detect the gene expression of typical ENS growth factors (GDNF, EGF, BFGF, NGF, and LIF), RT-PCR was performed using Qiagen One Step RT-PCR Kit on samples untreated (T0) and stimulated with Wnt3a $(20 \mathrm{ng} / \mathrm{mL})$ and LPS $(5 \mu \mathrm{g} / \mathrm{mL})$ for 1 (T1) and 7 (T7) days. RT-PCR products were electrophoresed on $2 \%$ agarose gel and stained by GelRed ${ }^{T M}$. HPRT was used as housekeeping gene.

signaling. It is known that in embryonic [89] and postnatal gut [90], the components of Wnt signaling are expressed in complex spatial and temporal patterns according to specific activities. Previous studies on Frizzled 9 in human and mouse have shown that it is highly expressed in the brain $[21,91]$ and in neural precursor cells during developing nervous system [36,92]. Moreover, FZD9 protein has been localized at growth cones of regenerating adult spiral ganglion neurons [93] suggesting to be involved in neuronal response to damage.
As previously reported [71], the cultures of dissociated postnatal gut give rise to multipotent ENS progenitors generating in vitro neurons and glia. Based on FSC morphological discrimination and positive reactivity to antiPAN neuronal marker by FCM analysis, the expression of FZD9 was demonstrated to characterize the neuronal compartment and to be preserved under $\mathrm{BM}$ and $\mathrm{SM}$ culture conditions.

During ENS development, there is a critical balance among migration, survival, proliferation, and differentiation of neural crest cells (NCCs). A fine control of 
these processes guarantees that a sufficient number of NCCs enter the foregut at the correct time while proliferation and differentiation are maintained at a balanced level at migration wavefront. It is known that the microenvironment plays a pivotal role to regulate the extent of ENS formation influencing on NCC number and gut colonization. Although neurotrophic factors are demonstrated to be essential for gut formation, the biological processes controlled by these factors are not yet completely elucidated $[94,95]$. In both BM and SM, a stem cell subset including enteric nervous stem cells (ENSCs) $[96,97]$ is maintained during in vitro culturing. $\mathrm{Nu}-$ merous evidences suggest that germinal niches are adjacent to myenteric ganglia, and myenteric plexus-derived preparations are enriched of ENSCs. Using genetic fate mapping of Sox10, a neural crest cell marker [98], it has demonstrated that in postnatal gut, Sox10 positive cells can act as neuroprogenitor cells and regenerate neurons after damage. CD34 has been demonstrated to be expressed in hematopoietic stem cells $[99,100]$, putative endothelial cells [101], and mesenchymal precursor cells [102]. In the gut, CD34 expression has been reported either in interstitial Cajal cells together with cKit, CD44 [103], and ENSC [104] that, likely committed lineage cells [71,105-108], are commonly characterized by p75 $[104,105]$ and Sox2 [106,109]. In our study, as previously shown by Hagl et al. [47], the expression of Nanog confirmed the existence of stem cells with high differentiative potentiality and the absence of cKit and CD44 led to consider CD34 as associated to an immature cell population rather than interstitial Cajal cells.

As suggested by the expression level of Sox10, p75, and GFAP, glial cells were stimulated under standard culture conditions while neuronal committed cells expressing Sox2, NG2 $[110,111]$, and PAN neuronal marker were in vitro maintained and numerically increased when deprived of bFGF, EGF, GDNF, and NGF. These evidences suggested that a diminished availability of neurotrophic factors fostered neuronal commitment of progenitors but negatively controlled the cell differentiation process as shown by lacking neurosphere formation. In contrast, under standard culture conditions, glial differentiation was promoted more than neuronal and neurospheres were regularly formed.

Under Wnt3a $(20 \mathrm{ng} / \mathrm{mL})$ and LPS $(5 \mu \mathrm{g} / \mathrm{mL})$ stimulation, neurospheres were demonstrated to increase in number and size. After 1 day of culture, the neurosphere diameter was $10 \mu \mathrm{m}$ bigger in LPS- and Wnt3a-treated samples than that observed in control. At T7, the number of neurospheres was doubled in LPS-treated samples compared to that detected under Wnt3a stimulation. Interestingly, a larger diameter of neurospheres was induced by Wnt3a with respect to LPS. The different proliferation effect could be indicative of a protective mechanism that, through the stimulation of immature cells but by the activation of different pathways, LPS [44] and Wnt3a [112] guaranteed a neural renewal.

Although FZD9 in human has been shown to bind Drosophila Wingless [91], the first evidence of its ability to activate $\mathrm{Wnt} / \beta$-catenin signaling through the binding of Wnt2 ligand was obtained from Karasawa et al. [37] by an in vitro rat model.

The interaction between Wnts and Frizzled receptors is specific and differently involved in physiological and pathological conditions $[3,113]$. In our case, the demonstrated ability of FZD9 to bind Wnt3a and the presence of Wnt3a in glial cells provided the evidence of a possible protective role exerted by glia on enteric neurons through the activation of Wnt canonical pathway at physiological state or pathological conditions [114].

Wnt1 and Wnt3a are coexpressed at the dorsal midline of the developing neural tube and control the midbrain patterning and the formation of the paraxial mesoderm, respectively. When a deficiency of both Wnt1 and Wnt3a is observed, the development of neural crest derivatives is compromised suggesting that local Wnt signaling regulates the expansion of dorsal neural precursors. Despite the high number of mammalian Wnt and Frizzled members, a poor characterization of Wnt Frizzled binding specificities is reported.

In particular, it is known that canonical Wnt signaling controls crypt progenitor gene expression pattern [115]. Recently, several studies have implied the involvement of canonical Wnt Frizzled signaling in inflammatory bowel disease (IBD) [21,31], as a significant increased expression of Wnt3a and Frizzled receptors are observed [114]. In the current study, the nuclear translocation of $\beta$-catenin in rat ENS cells under stimulation with exogenous Wnt3a suggested that canonical Wnt pathway is active in postnatal myenteric plexus and Frizzled 9 could be involved as a specific ligand. The transcriptional regulation of FZD9 after the treatment with Wnt3a suggested that it might play a role in the context of inflammation. Only little is known about the expression and function of FZD9 in postnatal ENS. Among frizzled receptors, we demonstrated that FZD9 protein was significantly expressed on freshly extracted ENS cells and maintained in ex vivo cultured neuronal population. As previously reported [94], the regulation by Wnt signaling could be interpreted as protective and might be involved in the ENS defense. Activated Wnt3a/ $\beta$-catenin signaling pathway is known to stimulate intestinal epithelial repair after wounding [116] and neural restricted precursor cell populations [117]. In our study, the binding specificity of Frizzled 9 with Wnt3a was demonstrated in ENS compartment and suggested the involvement of FZD9 in neuronal response to inflammation in light of the evidence that a significant increase of 
Wnt3a and FZD9 is observed in inflammatory bowel diseases [31]. The expression of TLR4 by the enteric neural cells highlighted the presence of a neural surveillance network that activates a cell-specific response against bacterial agents when the epithelial barrier permeability is altered [86]. In the present study, the expression of both TLR4 and Frizzled 9 was detected in the neuronal population, while glial cells were characterized only by TLR4. Our evidences suggested that a neuronal subset was responsive to inflammatory agents through TLR-based mechanism and was regulated by Frizzled 9-mediated canonical Wnt signaling.

The cross regulation of Wnt and NF-кB signaling pathways has been shown to modify the biological effects of gene expression during development, immune function, inflammation, and carcinogenesis. A wide spectrum of phosphorylation/acetylation events and associating proteins is demonstrated to modulate the activation or inhibition of $\beta$-catenin, NF-кB, or their binding activity to DNA [67], independently on specific stimuli. In the last two decades, a lot of experimental data have reported that the interplay between Wnt signaling and NF- $\mathrm{KB}$ is expressed at different levels and is subject to variations in dependence of PI3K/Akt pathway, cell type specificity, and physiological/pathological conditions [118].

In the present work, we have demonstrated that canonical Wnt signaling is active in ENS and cross talks with NF- $\mathrm{KB}$ modulating the response to LPS. Phosphorylation events at serine 473 activate Akt and lock it at active conformation [119]. In both standard and basal medium, the presence of nuclear $\beta$-catenin and NF-кB was observed in the absence of exogenous stimulation with Wnt3a and LPS and thus was correlated with active p(Ser473)-Akt.

As $p$ (Ser9)-GSK3 $\beta$ was detected only in standard medium and $p$ (Ser33)- $\beta$-catenin started to be expressed at T1h, we hypothesized that Akt controls phosphorylation events in resting cells promoting directly or indirectly both activation and degradation of $\beta$-catenin, besides nuclear translocation of NF-кB p65. It was demonstrated that Akt phosphorylates $\beta$-catenin at Ser552 leading first to its dissociation from cell-cell contacts and then to the increase of its binding to 1433 proteins and its transcriptional activity [120]. As GSK3 $\beta$ is active in resting cells and is inactivated through serine 9 phosphorylation induced by mitogens, growth factors, and several kinases, including Akt [121], we hypothesized that endogenous factors could contribute to regulated activation of Akt and control the stabilization of $\beta$ catenin by IKK $\alpha[65,67]$. Wnt- and FGF-dependent PI3K Akt signaling pathways cross talk during a variety of cellular processes including neurogenesis [122] and both lead to GSK3 $\beta$ downregulation although depending on different phosphorylation events. In contrast to FGF signaling, the canonical Wnt is reported to be independent on Ser 9 phosphorylation. In the present work, we demonstrated that Wnt3a and LPS cross talk at the level of GSK3 $\beta$ and deactivate it by Ser9 phosphorylation, even if other phosphorylation events are not excluded because our in vitro model is not based on the inhibition of PI3K/Akt signaling pathway but only on the deprivation of main ENS trophic factors. This activity is hypothesized to be specifically dependent on the activation of Wnt and NF- $\mathrm{KB}$ signaling, probably modulated by GSK3 $\beta$ but not depending on exogenous growth factors such as bFGF and EGF as the evidences were taken from basal medium-treated samples. The concomitant presence of $p($ Ser33)- $\beta$-catenin and $p(\operatorname{Ser} 9)$ GSK3 $\beta$ at early phase of Wnt3a and LPS stimulation suggested that alternative mechanisms of phosphorylation might occur promoting the negative control of $\beta$-catenin and thus its modulation. As the protein expression profile detected in standard and basal medium-treated samples showed a stronger accumulation of $\beta$-catenin at late phase of Wnt3a stimulation, GSK3 $\beta$ downregulation by simultaneous treatment with Wnt and growth factors is hypothesized to involve GSK3 $\beta$ pools differently modulated by Akt.

The critical role of Akt signaling for neuroprotection against deprivation of growth factors [123], oxidative stress [124], and ischemic injury [125] is evidenced from several in vitro studies on neuronal cell lines or primary cultures. Phosphorylation of Akt through phosphatidylinositol 3 kinase is essential to promote ENS precursor survival [8]. Akt level expression was correlated with a constitutive activation of a neuroprotective mechanism as previously reported by Humbert et al. [126]. Interestingly, in basal medium-treated samples, LPS response evidenced a superior expression level of nuclear $\beta$-catenin than that observed in ENS cells cultured in standard medium probably due to an interaction of Akt with GSK3 $\beta$ [127]. As BM-based in vitro model could simulate pathological conditions, wherein the limited or absent supply of growth factors promotes gut inflammation, the higher nuclear translocation of $\beta$-catenin could be interpreted as a negative regulation of NF- $\mathrm{KB}$ p 65 transcriptional activity.

As GSK3 $\beta$ has been shown to regulate NF-кB at the level of transcriptional complex [128] and $\beta$-catenin is a major substrate of GSK3 $\beta$, it is hypothesized that $\beta$-catenin might serve as a mediator for the cross regulation between Wnt and NF-KB signaling pathways at different levels and cellular compartments (Figure 7). The binding of $\beta$-catenin and NF- $\mathrm{KB}$ on specific regions of DNA is suggested to be fine regulated, as the activation and nuclear translocation of both transcription factors might be promoted without any specific stimulated signaling pathway, but only due to a cascade of phosphorylation events. 


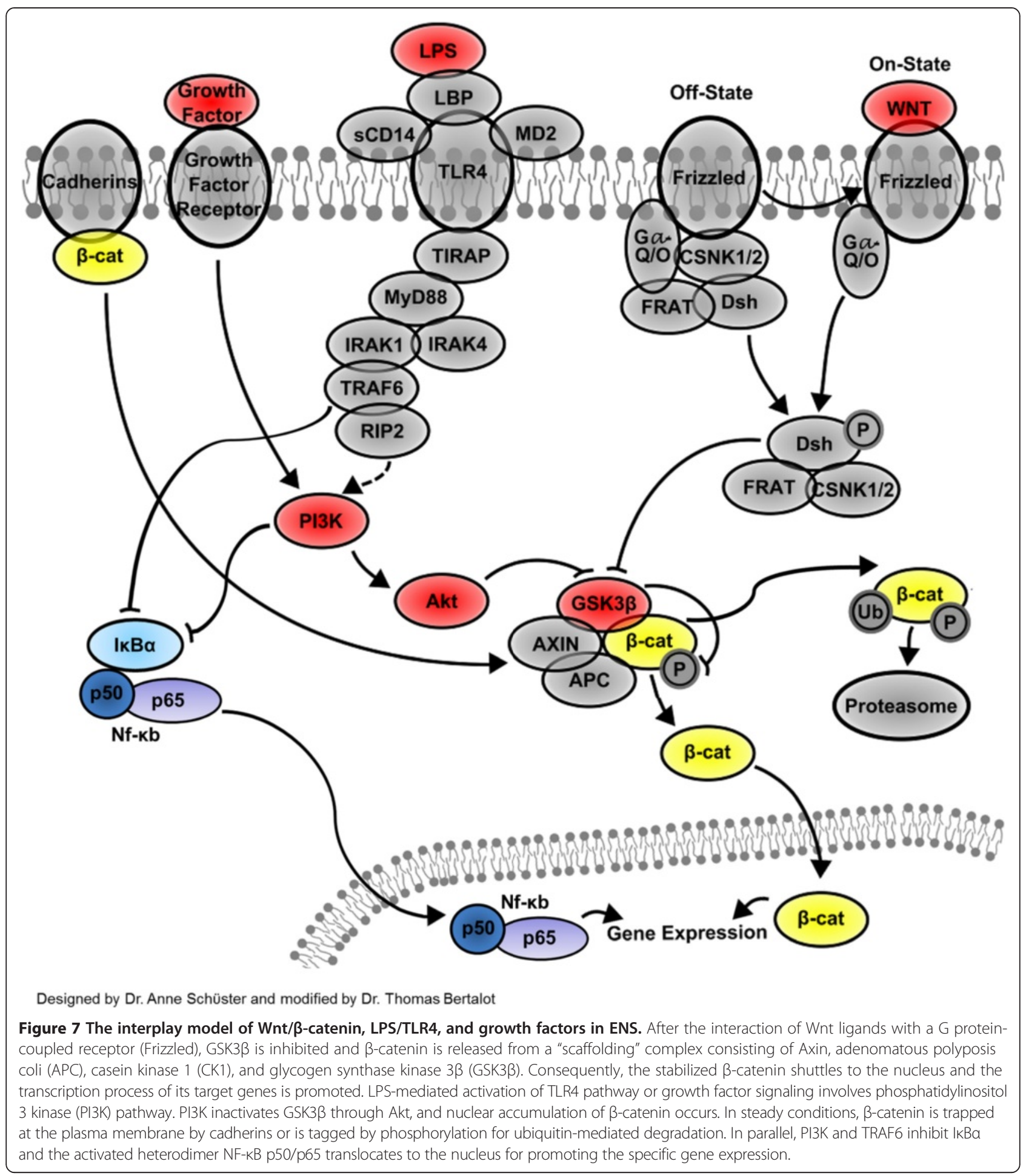

In the present study, using Co-IP technique, we demonstrated that nuclear $\beta$-catenin and NF-кB p65 could complex together or are present as free proteins in resting ENS cells. The $\beta$-catenin/p65 complex and the free proteins resulted to be differently expressed in dependence on experimental conditions. It is already reported that $\beta$-catenin can physically interact with p65 and p50 subunits to inhibit the binding of NF- $\mathrm{KB}$ to DNA in $\mathrm{I} \mathrm{K} \mathrm{B} \alpha$-independent manner and in association with additional cellular factors [78]. Interestingly, suppressed NF-кB activity and target gene expression were observed in cells expressing high level of $\beta$-catenin [78]. Hwang 
et al. [112] have proposed a model of combinatorial binding of p65 and $\beta$-catenin showing that the specific transcriptional activity of $\beta$-catenin is regulated by protein-protein interaction with p65 at transcriptional level of their target genes. As the promoters of Wnt signaling target genes contain NF- $\mathrm{KB}$ binding elements, in the absence of specific stimulation, a constitutive binding of $\beta$-catenin/p65 complex to NF-KB sites is suggested to block $\beta$-catenin transcriptional activity. After Wnt signaling activation, the nuclear accumulation of $\beta$-catenin leads to the displacement of $\mathrm{p} 65$ from gene promoters and to the binding of $\beta$-catenin TCF transcriptional complex to DNA. Under LPS activation, IKK $\alpha$-mediated phosphorylation of nuclear p65 subunit within the transactivation domains promotes the transient transcriptional activity of NF-кB target genes [67].

The major expression of $\beta$-catenin/NF-кB p65 complex in SM-treated samples was correlated to the greater accumulation of nuclear $\beta$-catenin and NF-KB p65 deriving from aspecific stimulation of NF-kB (or alternative NF-кB pathway) and Wnt signaling pathway exerted by trophic factors [127]. Only the stimulation with LPS resulted into the activation of canonical NF-кB pathway, as demonstrated by the nuclear presence of NF-кB p50/p65. This evidence confirmed that a large diversity of signals might converge on degradation of ІкBs, the known proteins that physically mask the nuclear localization signal (NLS) of NF-кB p65. However, the DNA binding activity of NF-кB to ІкB sites, among a large excess of potential binding sites, is specifically controlled by NF-KB subunits, associated proteins, and binding to nuclear chromatin.

The specific responsiveness of ENS cells to Wnt3a or LPS stimulation was confirmed evaluating the transcriptional activity of nuclear $\beta$-catenin and p65 subunit in samples cultured in basal medium. Both canonical Wnt signaling and NF- $\mathrm{KB}$ pathway are expressed in ENS and control gut homeostasis [129]. As the FZD9 expression was observed only in neuronal subpopulation while that of TLR4 resulted on both neurons and glial cells, we asked us which reciprocal regulation occurs between canonical Wnt pathway and NF-кB signaling in ENS neurons at physiological and inflamed conditions. The high level of GSK3 $\beta$ expression in brain tissue is likely due to its essential role in neuronal signaling. In neuronal cells, it is required for dendrite extension and synapse formation in newborns. Dysregulation of GSK3 $\beta$ expression leads to many pathological conditions, including neuronal dysfunction, Alzheimer's disease [130], and Parkinson's disease [131]. Highly expressed in colorectal cancer $[132,133]$, it has been shown to participate in NF-кBmediated cell survival in pancreatic cancer [134]. In cell culture studies, apoptosis is attenuated or fully abrogated by the inhibition of GSK3 $\beta$ in primary neurons [135] and neuronal cell lines [136]. The Wnt pathway is involved in regulation of gut homeostasis. Under intestinal inflammation, the expression level of Wnt3a significantly increases [31] and neuronal apoptosis is observed [60].

Schaale et al. [137] described a regulatory role of Wnt signaling in inflammatory processes and reported that exogenous Wnt3a mediates anti-inflammatory effects in macrophages promoting the suppression of proinflammatory cytokines. Moreover, Li et al. demonstrated that Wnt signaling contributes to Alzheimer's disease-related neurodegeneration by regulating neuroinflammation [138] and plays a crucial role in the expression of proinflammatory cytokines in the central nervous system [139]. In our study, LPS treatment enhanced the gene expression of FZD9 and Wnt3a but reduced the level of TLR4 mRNA, suggesting a possible negative feedback scenario in which a positive regulation of Wnt pathway could be exerted by NF-KB signaling to restore homeostatic conditions. This hypothesis was further confirmed evaluating that the specific LPS-mediated inflammatory response was reversed in the presence of Wnt3a as demonstrated by a reduced expression of $T N F a, I L 6$, and $I L 1 B$ genes and, interestingly, an increased level of IL10 mRNA. As it is reported that LPS-treated enteric neurons respond stimulating the secretion of inflammatory cytokines such as IL6, TNFa [129] to activate glial cells that, in turn, release IL1B, the inhibitory activity exerted by Wnt3a could be interpreted as effective to control glial activation.

Taken together these considerations, we concluded that Wnt3a exerts a negative control of NF-кB transcriptional activity in rat myenteric plexus and contributes to ENS defense by the stimulation of IL10, TLR4, and FZD9 expression. In turn, LPS balances the inflammatory response stimulating Wnt signaling and enhancing the transcription level of FZD9 and Wnt3a.

\section{Conclusions}

The results of this study suggested the existence of neuronal surveillance through FZD9 and Wnt3a in enteric myenteric plexus. As detected in freshly isolated ENS cells, FZD9 was hypothesized to be expressed in constitutive manner for some homeostatic activities. Although the total number of FZD9 positive cells cultured under standard and basal conditions did not significantly change, the expression level of FZD9 was upregulated in response to GDNF, bFGF, and NGF, suggesting a possible involvement of Wnt signaling in neuronal and glial differentiation. Interestingly, under in vitro-simulated inflammation, Wnt signaling was demonstrated to exert an anti-inflammatory activity to negatively control NF-кB pathway.

Competing interests

The authors declare that they have no competing interest. 


\section{Authors' contributions}

$\mathrm{RDL}$ and TB designed and performed the research, analyzed and interpreted the data, and wrote the manuscript. AS performed the research and analyzed the data. SS, AT, and IZ performed the research. MTC and KHS made the conception and design of experiments, performed the data analysis and interpretation, and did the final approval of the manuscript. All authors read and approved the final manuscript.

\section{Acknowledgments}

Padua University (Grant ex60\% Project) supported this work. We thank Prof. Pier Paolo Parnigotto and the Italian Association of Blood Donors (AVIS) of Veneto Region that contributed to acquire instrumental equipment (FACSCanto II cytometer). A special thanks to Silvia Barbon, Senthilkumar Rajendran, and Riccardo Sfriso for technical assistance.

\section{Author details}

${ }^{1}$ Department of Pharmaceutical and Pharmacological Sciences, University of Padova, Via Marzolo 5, 35131 Padova, Italy. ${ }^{2}$ Department of Biotechnology, University of Applied Sciences Kaiserslautern, Zweibrücken, Germany.

\section{Received: 15 October 2014 Accepted: 14 January 2015 Published online: 03 February 2015}

\section{References}

1. De Santa Barbara P, Van den Brink GR, Roberts DJ. Development and differentiation of the intestinal epithelium. Cell Mol Life Sci. 2003;60(7):1322-32.

2. Stuhlmiller TJ, García Castro MI. Current perspectives of the signalling pathways directing neural crest induction. Cell Mol Life Sci. 2012;69(22):3715-37.

3. Gregorieff A, Pinto D, Begthel H, Destrée O, Kielman M, Clevers H. Expression pattern of Wnt signaling components in the adult intestine. Gastroenterology. 2005;129(2):626-38.

4. Wodarz A, Nusse R. Mechanisms of Wnt signalling in development. Annu Rev Cell Dev Biol. 1998;14:59-88.

5. Bhanot $P$, Brink $M$, Samos $C H$, Hsieh JC, Wang $Y$, Macke JP, et al. A new member of the frizzled family from Drosophila functions as a wingless receptor. Nature. 1996:382(6588):225-30.

6. Katoh M. Cross talk of WNT and FGF signalling pathways at GSK3beta to regulate beta catenin and SNAIL signalling cascades. Cancer Biol Ther. 2006;5(9):1059-64.

7. Ojeda L, Gao J, Hooten KG, Wang E, Thonhoff JR, Dunn TJ, et al. Critical role of PI3K/Akt/GSK3 $\beta$ in motoneuron specification from human neural stem cells in response to FGF2 and EGF. PLoS One. 2011;6(8):e23414.

8. Srinivasan S, Anitha M, Mwangi S, Heuckeroth RO. Enteric neuroblasts require the phosphatidylinositol 3 kinase/Akt/forkhead pathway for GDNF stimulated survival. Mol Cell Neurosci. 2005;29(1):107-19.

9. Higuchi M, Onishi K, Masuyama N, Gotoh Y. The phosphatidylinositol 3 kinase (PI3K) Akt pathway suppresses neurite branch formation in NGF treated PC12 cells. Genes Cells. 2003;8(8):657-69.

10. Clevers $H$, Nusse R. Wnt/ $\beta$ catenin signalling and disease. Cell. 2012;149(6):1192-205.

11. Kalani MY, Cheshier SH, Cord BJ, Bababeygy SR, Vogel H, Weissman IL, et al. Wnt-mediated self-renewal of neural stem/progenitor cells. Proc Natl Acad Sci U S A. 2008;105(44):16970-5.

12. Polakis P. Wnt signalling and cancer. Genes Dev. 2000;14(15):1837-51.

13. Andoh A, Bamba S, Brittan M, Fujiyama Y, Wright NA. Role of intestinal subepithelial myofibroblasts in inflammation and regenerative response in the gut. Pharmacol Ther. 2007;114(1):94-106.

14. van de Wetering M, Sancho E, Verweij C, de Lau W, Oving I, Hurlstone A, et al. The beta-catenin/TCF-4 complex imposes a crypt progenitor phenotype on colorectal cancer cells. Cell. 2002:111(2):241-50.

15. Batlle $E$, Henderson JT, Beghtel H, van den Born MM, Sancho E, Huls G, et al. Beta-catenin and TCF mediate cell positioning in the intestinal epithelium by controlling the expression of EphB/ephrinB. Cell. 2002;111(2):251-63.

16. Logan CY, Nusse R. The Wnt signalling pathway in development and disease. Annu Rev Cell Dev Biol. 2004;20:781-810.

17. You XJ, Bryant PJ, Jurnak F, Holcombe RF. Expression of Wnt pathway components Frizzled and Disheveled in colon cancer arising in patients with inflammatory bowel disease. Oncol Rep. 2007;18(3):691-4.

18. Sun J, Hobert ME, Duan Y, Rao AS, He TC, Chang EB, et al. Crosstalk between NF-kappaB and beta-catenin pathways in bacterial-colonized intestinal epithelial cells. Am J Physiol Gastrointest Liver Physiol. 2005;289(1):G129-37.

19. Neumann J, Schaale K, Farhat K, Endermann T, Ulmer AJ, Ehlers S, et al. Frizzled 1 is a marker of inflammatory macrophages, and its ligand Wnt3a is involved in reprogramming Mycobacterium tuberculosis-infected macrophages. FASEB J. 2010;24(11):4599-612.

20. Manicassamy S, Reizis B, Ravindran R, Nakaya H, Salazar-Gonzalez RM, Wang YC, et al. Activation of beta-catenin in dendritic cells regulates immunity versus tolerance in the intestine. Science. 2010;329(5993):849-53.

21. Sen M, Ghosh G. Transcriptional outcome of Wnt Frizzled signal transduction in inflammation: evolving concepts. J Immunol. 2008;181(7):4441-5.

22. Cadigan KM, Nusse R. Wht signalling: a common theme in animal development. Genes Dev. 1997;11(24):3286-305.

23. Moon RT, Brown JD, Torres M. WNTs modulate cell fate and behavior during vertebrate development. Trends Genet. 1997;13(4):157-62.

24. Kühl M, Sheldahl LC, Park M, Miller JR, Moon RT. The Wnt/Ca2+ pathway: a new vertebrate Wnt signalling pathway takes shape. Trends Genet. 2000;16(7):279-83.

25. Parr BA, Shea MJ, Vassileva G, McMahon AP. Mouse Wnt genes exhibit discrete domains of expression in the early embryonic CNS and limb buds. Development. 1993;119(1):247-61

26. de Lau W, Barker N, Clevers H. WNT signalling in the normal intestine and colorectal cancer. Front Biosci. 2007;12:471-91.

27. Pinto $\mathrm{D}$, Clevers $\mathrm{H}$. Wht control of stem cells and differentiation in the intestinal epithelium. Exp Cell Res. 2005;306(2):357-63.

28. Kawaguchi J, Nichols J, Gierl MS, Faial T, Smith A. Isolation and propagation of enteric neural crest progenitor cells from mouse embryonic stem cells and embryos. Development. 2010;137(5):693-704.

29. Koch S, Nava P, Addis C, Kim W, Denning TL, Li L, et al. The Wnt antagonist Dkk1 regulates intestinal epithelial homeostasis and wound repair Gastroenterology. 2011;141(1):259-68. 268.e1 8

30. Sokol SY. Maintaining embryonic stem cell pluripotency with Wnt signalling. Development. 2011;138(20):4341-50.

31. You J, Nguyen AV, Albers CG, Lin F, Holcombe RF. Wnt pathway related gene expression in inflammatory bowel disease. Dig Dis Sci. 2008;53(4):1013-9.

32. Rulifson EJ, Wu CH, Nusse R. Pathway specificity by the bifunctional receptor frizzled is determined by affinity for wingless. Mol Cell. 2000;6(1):117-26.

33. Wu CH, Nusse R. Ligand receptor interactions in the Wht signalling pathway in Drosophila. J Biol Chem. 2002;277(44):41762-9.

34. Takada R, Hijikata H, Kondoh H, Takada S. Analysis of combinatorial effects of Wnts and Frizzleds on beta catenin/armadillo stabilization and Dishevelled phosphorylation. Genes Cells. 2005;10(9):919-28.

35. Wang YK, Spörle R, Paperna T, Schughart K, Francke U. Characterization and expression pattern of the Frizzled gene Fzd9, the mouse homolog of FZD9 which is deleted in Williams Beuren syndrome. Genomics. 1999:57(2):235-48

36. Van Raay TJ, Wang YK, Stark MR, Rasmussen JT, Francke U, Vetter ML, et al. Frizzled 9 is expressed in neural precursor cells in the developing neural tube. Dev Genes Evol. 2001;211(8 9):453-7.

37. Karasawa T, Yokokura H, Kitajewski J, Lombroso PJ. Frizzled 9 is activated by Wnt 2 and functions in Wnt/beta catenin signalling. J Biol Chem. 2002;277(40):37479-86

38. Cai J, Wu Y, Mirua T, Pierce $J$, Lucero MT, Albertine KH, et al. Properties of a fetal multipotent neural stem cell (NEP cell). Dev Biol. 2002;251(2):221-40.

39. Schäfer $\mathrm{KH}$, Mestres $P$. The GDNF induced neurite outgrowth and neuronal survival in dissociated myenteric plexus cultures of the rat small intestine decreases postnatally. Exp Brain Res. 1999;125:447-52.

40. Friedman WJ, Greene LA. Neurotrophin signalling via Trks and p75. Exp Cell Res. 1999:253:131-42.

41. Chadi G, Gomide VC, Rodrigues de Souza R, Scabello RT, Maurício da Silva C. Basic fibroblast growth factor, neurofilament, and glial fibrillary acidic protein immunoreactivities in the myenteric plexus of the rat esophagus and colon. J Morphol. 2004:261(3):323-33.

42. McLeay LM, Comeskey MA, Waters MJ. Effects of epidermal growth factor on gastrointestinal electromyographic activity of conscious sheep. J Endocrinol. 1990;124:109-15.

43. Chalazonitis A, Rothman TP, Chen J, Vinson EN, MacLennan AJ, Gershon MD. Promotion of the development of enteric neurons and glia by 
neuropoietic cytokines: interactions with neurotrophin 3. Dev Biol. 1998;198:343-65.

44. Schuster A, Klotz M, Schwab T, Di Liddo R, Bertalot T, Schrenk S, et al. Maintenance of the enteric stem cell niche by bacterial lipopolysaccharides? Evidence and perspectives. J Cell Mol Med. 2014;18(7):1429-43.

45. Moore MW, Klein RD, Farinas I, Sauer H, Armanini M. Renal and neuronal abnormalities in mice lacking GDNF. Nature. 1996;382:76-9.

46. Kuroda T, Ueda M, Nakano M, Saeki M. Altered production of nerve growth factor in aganglionic intestines. J Pediatr Surg. 1994;29(2):288-92. discussion 2923.

47. Hagl Cl, Heumüller Klug S, Wink E, Wessel L, Schäfer KH. The human gastrointestinal tract, a potential autologous neural stem cell source. PLoS One. 2013;8(9):e72948.

48. Wester $T$, Olsen L. Expression of leukaemia inhibitory factor during the development of the human enteric nervous system. Histochem J. 2000;32(6):345-8.

49. Rusmini M, Griseri P, Lantieri F, Matera I, Hudspeth KL, Roberto A, et al. Induction of RET dependent and independent pro-inflammatory programs in human peripheral blood mononuclear cells from Hirschsprung patients. PLoS One. 2013;8(3):e59066.

50. Ding VM, Ling L, Natarajan S, Yap MG, Cool SM, Choo AB. FGF-2 modulates Wht signaling in undifferentiated hESC and iPS cells through activated PI3-K/GSK3beta signaling. J Cell Physiol. 2010;225(2):417-28.

51. Mwangi S, Anitha M, Fu H, Sitaraman SV, Srinivasan S. Glial cell line derived neurotrophic factor mediated enteric neuronal survival involves glycogen synthase kinase 3beta phosphorylation and coupling with 1433. Neuroscience. 2006;143(1):241-51.

52. Frykman PK, Short SS. Hirschsprung associated enterocolitis: prevention and therapy. Semin Pediatr Surg. 2012;21(4):328-35.

53. Cirillo C, Sarnelli G, Turco F, Mango A, Grosso M, Aprea G, et al. Proinflammatory stimuli activates human-derived enteroglial cells and induces autocrine nitric oxide production. Neurogastroenterol Motil. 2011;23(9):e372-82.

54. Dodd PR. Excited to death: different ways to lose your neurones. Biogerontology. 2002;3(1 2):51-6.

55. Lien E, Means TK, Heine $H$, Yoshimura A, Kusumoto S, Fukase $K$, et al, Toll-like receptor 4 imparts ligand-specific recognition of bacterial lipopolysaccharide. J Clin Invest. 2000;105(4):497-504

56. Chow JC, Young DW, Golenbock DT, Christ WJ, Gusovsky F. Toll like receptor 4 mediates lipopolysaccharide induced signal transduction. J Biol Chem. 1999;274:10689-92.

57. Cario E, Podolsky DK. Intestinal epithelial TOLLerance versus inTOLLerance of commensals. Mol Immunol. 2005;42(8):887-93. 23.

58. Medert R, Schuster A, Schwarz LK, Schwab T, Schaefer KH. Spiking rate of myenteric neurons recorded from multi electrode arrays depending on local microenvironment. Phys Status Solidi C. 2013;10(5):877-81.

59. Dobrovolskaia MA, Vogel SN. Toll receptors, CD14, and macrophage activation and deactivation by LPS. Microbes Infect. 2002;4:903-14.

60. Arciszewski M, Pierzynowski S, Ekblad E. Lipopolysaccharide induces cell death in cultured porcine myenteric neurons. Dig Dis Sci. 2005:50(9):1661-8.

61. Okun E, Griffioen KJ, Mattson MP. Toll like receptor signalling in neural plasticity and disease. Trends Neurosci. 2011;34:269-81.

62. Monick MM, Carter AB, Robeff PK, Flaherty DM, Peterson MW, Hunninghake GW. Lipopolysaccharide activates Akt in human alveolar macrophages resulting in nuclear accumulation and transcriptional activity of beta-catenin. J Immunol. 2001;166(7):4713-20

63. Arciszewski MB, Sand E, Ekblad E. Vasoactive intestinal peptide rescues cultured rat myenteric neurons from lipopolysaccharide induced cell death. Regul Pept. 2008;146(1 3):218-23.

64. He Z, Gao Y, Deng Y, Li W, Chen Y, Xing S, et al. Lipopolysaccharide induces lung fibroblast proliferation through toll-like receptor 4 signaling and the phosphoinositide3-kinase-Akt pathway. PLoS One. 2012;7(4):e35926.

65. Lamberti C, Lin KM, Yamamoto Y, Verma U, Verma IM, Byers S, et al. Regulation of beta-catenin function by the IkappaB kinases. J Biol Chem. 2001;276(45):42276-86

66. Häcker H, Karin M. Regulation and function of IKK and IKK related kinases. Sci STKE. 2006;2006(357):re13.

67. Wan F, Lenardo MJ. Specification of DNA binding activity of NF kappaB proteins. Cold Spring Harb Perspect Biol. 2009;1(4):a000067.

68. Nusse R. Wnt signalling and stem cell control. Cell Res. 2008;18:523-7.

69. Katoh M. WNT signalling pathway and stem cell signalling network. Clin Cancer Res. 2007;13:4042-5.
70. Kleber M, Sommer L. Wnt signalling and the regulation of stem cell function. Curr Opin Cell Biol. 2004;16:681-7.

71. Vasina V, Barbara G, Talamonti L, Stanghellini V, Corinaldesi R, Tonini M, et al. Enteric neuroplasticity evoked by inflammation. Auton Neurosci. 2006;126-127:264-72.

72. Bondurand N, Natarajan D, Thapar N, Atkins C, Pachnis V. Neuron and glia generating progenitors of the mammalian enteric nervous system isolated from foetal and postnatal gut cultures. Development. 2003;130:6387-400.

73. Wood JD. Enteric neuroimmunophysiology and pathophysiology. Gastroenterology. 2004;127:635-57.

74. Ikeya M, Lee SM, Johnson JE, McMahon AP, Takada S. Wnt signalling required for expansion of neural crest and CNS progenitors. Nature. 1997;389:966-70

75. Verzi MP, Shivdasani RA. Wnt signalling in gut organogenesis. Organogenesis. 2008:4(2):87-91.

76. Schäfer KH, Saffrey MJ, Burnstock G, Mestres VP. A new method for the isolation of myenteric plexus from the newborn rat gastrointestinal tract. Brain Res Brain Res Protoc. 1997;1(2):109-13.

77. Bonifacino JS, Dell'Angelica EC. Immunoprecipitation. Curr Protoc Cell Biol. 2001; Chapter 7:Unit 7.2

78. Deng J, Miller SA, Wang HY, Xia W, Wen Y, Zhou BP, et al. Beta-catenin interacts with and inhibits NF-kappa B in human colon and breast cancer. Cancer Cell. 2002;2(4):323-34.

79. Storsteen KA, Kernohan JW, Bargen JA. The myenteric plexus in chronic ulcerative colitis. Surg Gynecol Obstet. 1953:97(3):335-43.

80. Davis DR, Dockerty MB, Mayo CW. The myenteric plexus in regional enteritis: a study of the number of ganglion cells in the ileum in 24 cases. Surg Gynecol Obstet. 1955;101(2):208-16.

81. Dvorak AM, Monahan RA, Osage JE, Dickersin GR. Crohn's disease: transmission electron microscopic studies. II. Immunologic inflammatory response: alterations of mast cells, basophils, eosinophils, and the microvasculature. Hum Pathol. 1980;11(6):606-19.

82. Villanacci V, Bassotti G, Nascimbeni R, Antonelli E, Cadei M, Fisogni S, et al. Enteric nervous system abnormalities in inflammatory bowel diseases. Neurogastroenterol Motil. 2008;20(9):1009-16.

83. Lomax $A E$, Fernandez $E$, Sharkey KA. Plasticity of the enteric nervous system during intestinal inflammation. Neurogastroenterol Motil. 2005;17:4-15.

84. Schäfer $\mathrm{KH}$, Van Ginneken C, Copray S. Plasticity and neural stem cells in the enteric nervous system. Anat Rec (Hoboken). 2009;292:1940-52.

85. Rumio C, Besusso D, Arnaboldi F, Palazzo M, Selleri S, Gariboldi S, et al. Activation of smooth muscle and myenteric plexus cells of jejunum via toll-like receptor 4. J Cell Physiol. 2006;208(1):47-54.

86. Barajon I, Serrao G, Arnaboldi F, Opizzi E, Ripamonti G, Balsari A, et al. Toll-like receptors 3, 4, and 7 are expressed in the enteric nervous system and dorsal root ganglia. J Histochem Cytochem. 2009;57(11):1013-23.

87. Metzger M, Caldwell C, Barlow AJ, Burns AJ, Thapar N. Enteric nervous system stem cells derived from human gut mucosa for the treatment of aganglionic gut disorders. Gastroenterology. 2009;136:2214-25. e1-3.

88. Ruhl A. Glial cells in the gut. Neurogastroenterol Motil. 2005;17:777-90.

89. Na T, Tabin CJ. Wnt signalling during development of the gastrointestinal tract. Dev Biol. 2003;259:258-71.

90. Leedham SJ, Rodenas-Cuadrado P, Howarth K, Lewis A, Mallappa S, Segditsas $S$, et al. A basal gradient of Wnt and stem-cell number influences regional tumour distribution in human and mouse intestinal tracts. Gut. 2013:62(1):83-93.

91. Wang YK, Samos CH, Peoples R, Pérez-Jurado LA, Nusse R, Francke U. A novel human homologue of the Drosophila Frizzled Wnt receptor gene binds wingless protein and is in the Williams syndrome deletion at 7q11.23. Hum Mol Genet. 1997;6(3):465-72.

92. Chang $\mathrm{CH}$, Tsai RK, Tsai MH, Lin YH, Hirobe T. The roles of Frizzled 3 and Wnt3a on melanocyte development: in vitro studies on neural crest cells and melanocyte precursor cell lines. J Dermatol Sci. 2014;75(2):100-8.

93. Shah SM, Kang YJ, Christensen BL, Feng AS, Kollmar R. Expression of Wnt receptors in adult spiral ganglion neurons: Frizzled 9 localization at growth cones of regenerating neurites. Neuroscience. 2009;164(2):478-87.

94. Gianino S, Grider JR, Cresswell J, Enomoto H, Heuckeroth RO. GDNF availability determines enteric neuron number by controlling precursor proliferation. Development. 2003;130(10):2187-98.

95. Becker L, Kulkarni S, Tiwari G, Micci MA, Pasricha PJ. Divergent fate and origin of neurosphere like bodies from different layers of the gut. Am J Physiol Gastrointest Liver Physiol. 2012;302(9):G958-65. 
96. Rauch U, Hänsgen A, Hagl C, Holland Cunz S, Schäfer KH. Isolation and cultivation of neuronal precursor cells from the developing human enteric nervous system as a tool for cell therapy in dysganglionosis. Int J Colorectal Dis. 2006;21(6):554-9.

97. Almond S, Lindley RM, Kenny SE, Connell MG, Edgar DH. Characterisation and transplantation of enteric nervous system progenitor cells. Gut. 2007:56(4):489-96.

98. Laranjeira C, Sandgren K, Kessaris N, Richardson W, Potocnik A, Vanden Berghe $P$, et al. Glial cells in the mouse enteric nervous system can undergo neurogenesis in response to injury. J Clin Invest. 2011;121(9):3412-24.

99. Rafii S, Shapiro F, Rimarachin J, Nachman RL, Ferris B, Weksler B, et al. Isolation and characterization of human bone marrow microvascular endothelial cells: hematopoietic progenitor cell adhesion. Blood. 1994;84(1):10-9.

100. Holyoake TL, Alcorn MJ. CD34+ positive haemopoietic cells: biology and clinical applications. Blood Rev. 1994;8:113-24.

101. Asahara T, Murohara T, Sullivan A, Silver M, van der Zee R, Li T, et al. Isolation of putative progenitor endothelial cells for angiogenesis. Science. 1997;275(5302):964-7.

102. Zvaifler NJ, Marinova-Mutafchieva L, Adams G, Edwards CJ, Moss J, Burger JA, et al. Mesenchymal precursor cells in the blood of normal individuals. Arthritis Res. 2000;2(6):477-88

103. Sanders KM, Ordög T, Koh SD, Torihashi S, Ward SM. Development and plasticity of interstitial cells of Cajal. Neurogastroenterol Motil. 1999;11(5):311-38.

104. Suarez Rodriguez R, Belkind GJ. Cultured nestin positive cells from postnatal mouse small bowel differentiate ex vivo into neurons, glia, and smooth muscle. Stem Cells. 2004;22:1373-85.

105. Kruger GM, Mosher JT, Bixby S, Joseph N, Iwashita T, Morrison SJ. Neural crest stem cells persist in the adult gut but undergo changes in selfrenewal, neuronal subtype potential, and factor responsiveness. Neuron. 2002;35(4):657-69.

106. Heanue T, Pachnis $V$. Prospective identification and isolation of enteric nervous system progenitors using Sox2. Stem Cells. 2011;29:128-40.

107. Lake Jl, Heuckeroth RO. Enteric nervous system development: migration, differentiation, and disease. Am J Physiol Gastrointest Liver Physiol. 2013;305(1):G1-24.

108. Joseph NM, He S, Quintana E, Kim YG, Núñez G, Morrison SJ. Enteric glia are multipotent in culture but primarily form glia in the adult rodent gut. J Clin Invest. 2011;121(9):3398-411.

109. Graham V, Khudyakov J, Ellis P, Pevny L. SOX2 functions to maintain neural progenitor identity. Neuron. 2003;39(5):749-65.

110. Richardson WD, Young KM, Tripathi RB, McKenzie I. NG2 glia as multipotent neural stem cells: fact or fantasy? Neuron. 2011;70:661-73.

111. Nishiyama A, Komitova M, Suzuki R, Zhu X. Polydendrocytes (NG2 cells): multifunctional cells with lineage plasticity. Nat Rev Neurosci. 2009;10(1):9-22.

112. Hwang I, Choi YS, Jeon MY, Jeong S. NF kB p65 represses $\beta$ catenin activated transcription of cyclin D1. Biochem Biophys Res Commun. 2010:403(1):79-84.

113. Lickert H, Kutsch S, Kanzler B, Tamai Y, Taketo MM, Kemler R. Formation of multiple hearts in mice following deletion of beta-catenin in the embryonic endoderm. Dev Cell. 2002;3(2):171-81.

114. Liu L, Rao JN, Zou T, Xiao L, Smith A, Zhuang R, et al. Activation of Wnt3a signaling stimulates intestinal epithelial repair by promoting c-Mycregulated gene expression. Am J Physiol Cell Physiol. 2012;302(1):C277-85.

115. Crosnier C, Stamataki D, Lewis J. Organizing cell renewal in the intestine: stem cells, signals and combinatorial control. Nat Rev Genet. 2006;7(5):349-59.

116. Kalyani A, Hobson K, Rao MS. Neuroepithelial stem cells from the embryonic spinal cord: isolation, characterization, and clonal analysis. Dev Biol. 1997;186(2):202-23.

117. Rao MS. Multipotent and restricted precursors in the central nervous system. Anat Rec. 1999;257(4):137-48.

118. Cohen P, Frame S. The renaissance of GSK3. Nat Rev Mol Cell Biol. 2001;2:769-76.

119. Alessi DR, Andjelkovic M, Caudwell B, Cron P, Morrice N, Cohen P, et al. Mechanism of activation of protein kinase $B$ by insulin and IGF-1. EMBO J. 1996;15(23):6541-51.

120. Fang D, Hawke D, Zheng Y, Xia Y, Meisenhelder J, Nika H, et al. Phosphorylation of beta-catenin by AKT promotes beta-catenin transcriptional activity. J Biol Chem. 2007:282(15):11221-9.

121. Cross DA, Alessi DR, Cohen P, Andjelkovich M, Hemmings BA. Inhibition of glycogen synthase kinase 3 by insulin mediated by protein kinase B. Nature. 1995;378(6559):785-9.
122. Villanueva S, Glavic A, Ruiz P, Mayor R. Posteriorization by FGF, Wnt, and retinoic acid is required for neural crest induction. Dev Biol. 2002;241:289-301.

123. Dudek H, Datta SR, Franke TF, Birnbaum MJ, Yao R, Cooper GM, et al. Regulation of neuronal survival by the serine-threonine protein kinase Akt. Science. 1997;275(5300):661-5.

124. Salinas M, Martin D, Alvarez A, Cuadrado A. Akt1/PKBalpha protects PC12 cells against the parkinsonism inducing neurotoxin 1 methyl 4 phenylpyridinium and reduces the levels of oxygen free radicals. Mol Cell Neurosci. 2001;17:67-77.

125. Noshita N, Lewén A, Sugawara T, Chan PH. Akt phosphorylation and neuronal survival after traumatic brain injury in mice. Neurobiol Dis. 2002;9(3):294-304.

126. Humbert S, Bryson EA, Cordelières FP, Connors NC, Datta SR, Finkbeiner S, et al. The IGF-1/Akt pathway is neuroprotective in Huntington's disease and involves Huntingtin phosphorylation by Akt. Dev Cell. 2002;2(6):831-7.

127. Kane LP, Shapiro VS, Stokoe E, Weiss A. Induction of NF kB by the Akt/PKB kinase. Curr Biol. 1999:9:601-4.

128. Hoeflich KP, Luo J, Rubie EA, Tsao MS, Jin O, Woodgett JR. Requirement for glycogen synthase kinase-3beta in cell survival and NF-kappaB activation. Nature. 2000;406(6791):86-90.

129. Anitha M, Vijay Kumar M, Sitaraman SV, Gewirtz AT, Srinivasan S. Gut microbial products regulate murine gastrointestinal motility via toll like receptor 4 signalling. Gastroenterology. 2012;143(4):1006-16. e4.

130. Cohen P, Goedert M. GSK3 inhibitors: development and therapeutic potential. Nat Rev Drug Discov. 2004;3(6):479-87.

131. Kozikowski AP, Gaisina IN, Petukhov PA, Sridhar J, King LT, Blond SY, et al. Highly potent and specific GSK-3beta inhibitors that block tau phosphorylation and decrease alpha-synuclein protein expression in a cellular model of Parkinson's disease. ChemMedChem. 2006;1(2):256-66.

132. Shakoori A, Ougolkov A, Yu ZW, Zhang B, Modarressi MH, Billadeau DD, et al. Deregulated GSK3beta activity in colorectal cancer: its association with tumor cell survival and proliferation. Biochem Biophys Res Commun. 2005;334(4):1365-73.

133. Shakoori A, Mai W, Miyashita K, Yasumoto K, Takahashi Y, Ooi A, et al. Inhibition of GSK-3 beta activity attenuates proliferation of human colon cancer cells in rodents. Cancer Sci. 2007;98(9):1388-93.

134. Ougolkov AV, Fernandez Zapico ME, Savoy DN, Urrutia RA, Billadeau DD. Glycogen synthase kinase 3 beta participates in nuclear factor kappaB mediated gene transcription and cell survival in pancreatic cancer cells. Cancer Res. 2005;65(6):2076-81.

135. Cross DA, Culbert AA, Chalmers KA, Facci L, Skaper SD, Reith AD. Selective small-molecule inhibitors of glycogen synthase kinase-3 activity protect primary neurones from death. J Neurochem. 2000;77(1):94-102.

136. Culbert AA, Brown MJ, Frame S, Hagen T, Cross DA, Bax B, et al. GSK-3 inhibition by adenoviral FRAT1 overexpression is neuroprotective and induces Tau dephosphorylation and beta-catenin stabilisation without elevation of glycogen synthase activity. FEBS Lett. 2001;507(3):288-94.

137. Schaale K, Neumann J, Schneider D, Ehlers S, Reiling N. Wht signalling in macrophages: augmenting and inhibiting mycobacteria induced inflammatory responses. Eur J Cell Biol. 2011;90(6 7):553-9.

138. Li B, Zhong L, Yang X, Andersson T, Huang M, Tang SJ. WNT5A signalling contributes to $A \beta$-induced neuroinflammation and neurotoxicity. PLOS One. 2011;6(8):e22920.

139. Li B, Shi Y, Shu J, Gao J, Wu P, Tang SJ. Wingless-type mammary tumor virus integration site family, member $5 \mathrm{~A}$ (Wnt5a) regulates human immunodeficiency virus type 1 (HIV-1) envelope glycoprotein 120 (gp120)-induced expression of pro-inflammatory cytokines via the $\mathrm{Ca} 2+$ /calmodulin-dependent protein kinase II (CaMKII) and c-Jun N-terminal kinase (JNK) signalling pathways. J Biol Chem. 2013;288(19):13610-9. 